\title{
The Effects of Nuclear Electromagnetic Pulse (EMP) on Nuclear Power Plants
}

\author{
P. R. Barnes \\ R. W. Manweiler \\ R. R. Davis
}




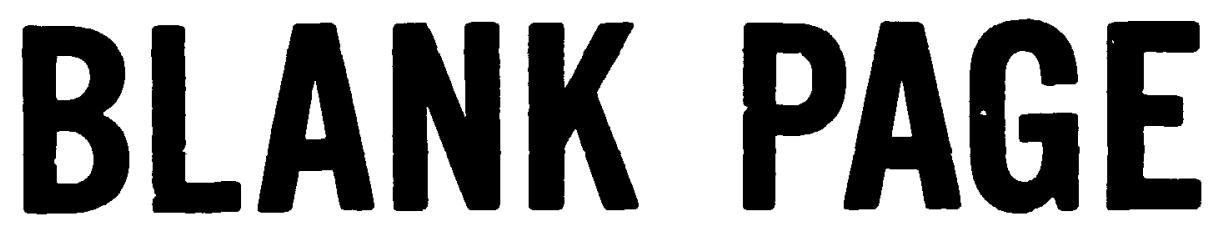


Dirtug ri ine Unted States of America Awalable trom

Natonal Technicai informairon Seruce

U.S Department J! Commerce

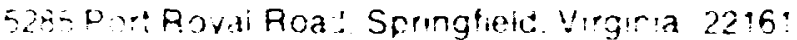

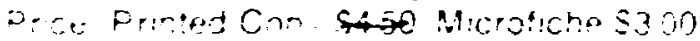

$\$ 4,5$

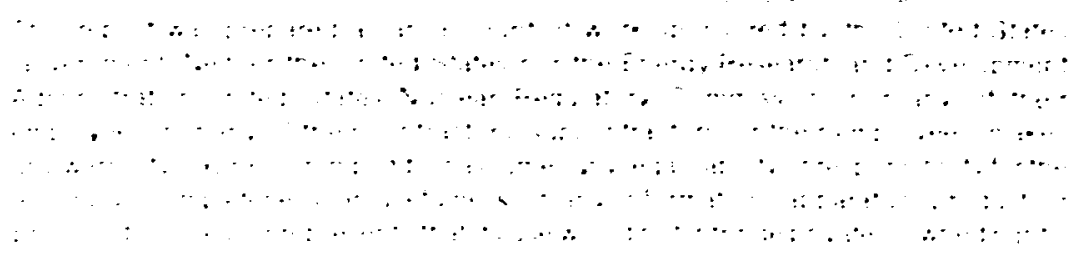


ORNL-50ay

Dist. Category $\mathrm{UC}-35$

Contract No. M-7405-eng-26

\author{
ENERGY DIVISION \\ Emergency Technology Program
}

THE EFFECTS OF NUCLEAR ELECTRCMAgNeTIC PULLSE

(EMP) ON NUCLEAR PONER PLANTS
P. R. Barnes
R. H. Manweiler
R. R. Davis

Research sponsored by tive Dirision of Biomedical and Environmental Pesearch, Enercy Research and Development. Administration, under contrac: with the Union Carbide Corporation.

$$
\text { Date Publisher. - September } 1977
$$

OAK RIOGE NATIONAL LABOP.ATORY Oak Ridge, Tennessee 37830 operated by UNION CARBIOE CORPORATION

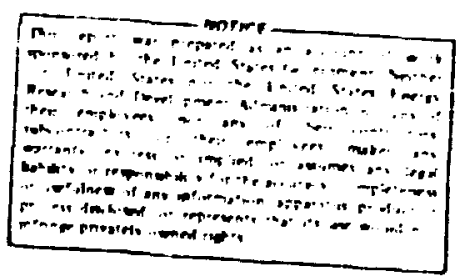
for the ENERGY RESEARCH ANC DEVELOPMENT ADMINISTRATION 


\section{CONTENTS}

Page

LIST OF FIGURES ..................

LIST OF TABLES ................... vii

FOREWORD ......................... ix

GLOSSARY OF ACROHYHS ................. xi

ABSTRACT ........................ 1

1. INTROOUCTION ...................... I

1.1 Purpose and Content ............... 1

1.2 High-Altitude EMP . . . . . . . . . . 2

1.3 The EMP Threat ............... 4

2. MODERM MUCLEAR PJUER PLANTS ............ 4

2.1 Intrnduction ................. 4

2.2 Pressurized-Hater Reactors . . . . . . . . 7

2.3 Boiling-Water Reactors ............ 8

2.4 Instrumentation and Controls .......... 11

2.5 Piant Electrical Power ............ 12

3. EMP SYSTEMS AMALYSIS . . . . . . . . . . . 12

3.1 Approach .................. 12

3.2 EMP Surges . . . . . . . . . . . 14

3.3 Plant Noise and Transient Protection ........ . .

3.4 Instrumentation and Control Systems ........ ?

3.4.1 PUR Instrumentation and Controis ....... $2 \mathrm{i}$

3.4.2 BWR Instrumentati $n$ and Controls ...... 24

3.5 The Reactor Monitoring System .......... 30

3.6 Plant Electrical Power . . . . . . . . . . . 33

4. CONSEQUENCES, COLNTERMEASURES, AND CONCLUSIONS . . . . . 34

4.1 EMP Events . . . . . . . . . . . . . 34

4.2 A Reactor Scram ................ 34

4.3 Actuation of Safety Systems . . . . . . . . 35

4.4 Loss of Electrical Auxiliary Power ......... 35

4.5 Loss of Instrument and Control Power ........ . 3.

4.6 Count. rmeasures . . . . . . . . . . . . 37

4.7 Conclusions ....................... . . . .

REFERENCES . . . . . . . . . . . . . . . . . . . 39 


\section{LIST OF FIGURES}

Page

1.1 Area of Co a-jge of EMf from High-Altitude Detonation.

1.2 Double Expingantidi di:e Form used to Represent the EMP E:E: $: i$ : Hir' fime History ........... 5

2.1 Simpitifie : Plant...................... 6

2.2 Simplificas

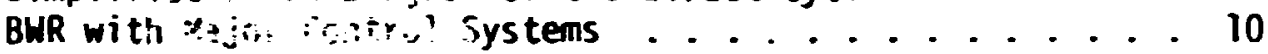

3.1 EMP Surgas at $5: 15$

3.2 The Open : . ! ? ? Induced on a 160-m Unshie!rea : $: 3$ ove the Earth by the

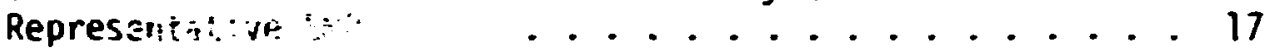

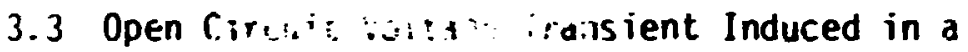

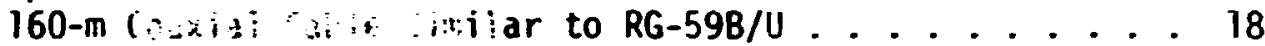

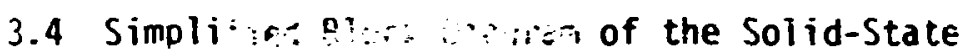
Proter? ir. $y-$. . . . . . . . . . . . . 22

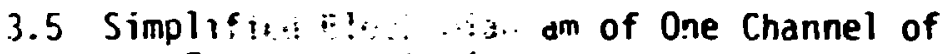
the fo: . . . . . . . . . . . . 23

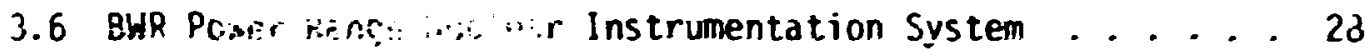

3.7 Simplifing Variat:" . . . . . . . . . . . . . 22 
vij

\section{LIST OF TABLES}

Page

3.1 EMP Cable Surges . . . . . . . . . . . . . . . . 19

3.2 EMP Effects on PWR Instrumentation and Controls . . . . . 25

3.3 BHR Instrumentation and Control Systems . . . . . . . 31 


\section{FOREHORD}

The EMP surge estimates given in this report are, in many cases, the upper tound for the actual surges that will be experienced in a nuclear power plant. These estimates were obtained by applying the maximun EMP coupling conditions to long cables (160 m) routed near the exterior wall which is illuminated by the incident EMP. These worstcase surges were used along with conservative assumptions to determine the effects of EMP on important plant systems. Therefore, the conclusions of this report are considered conservative and pessimistic. 


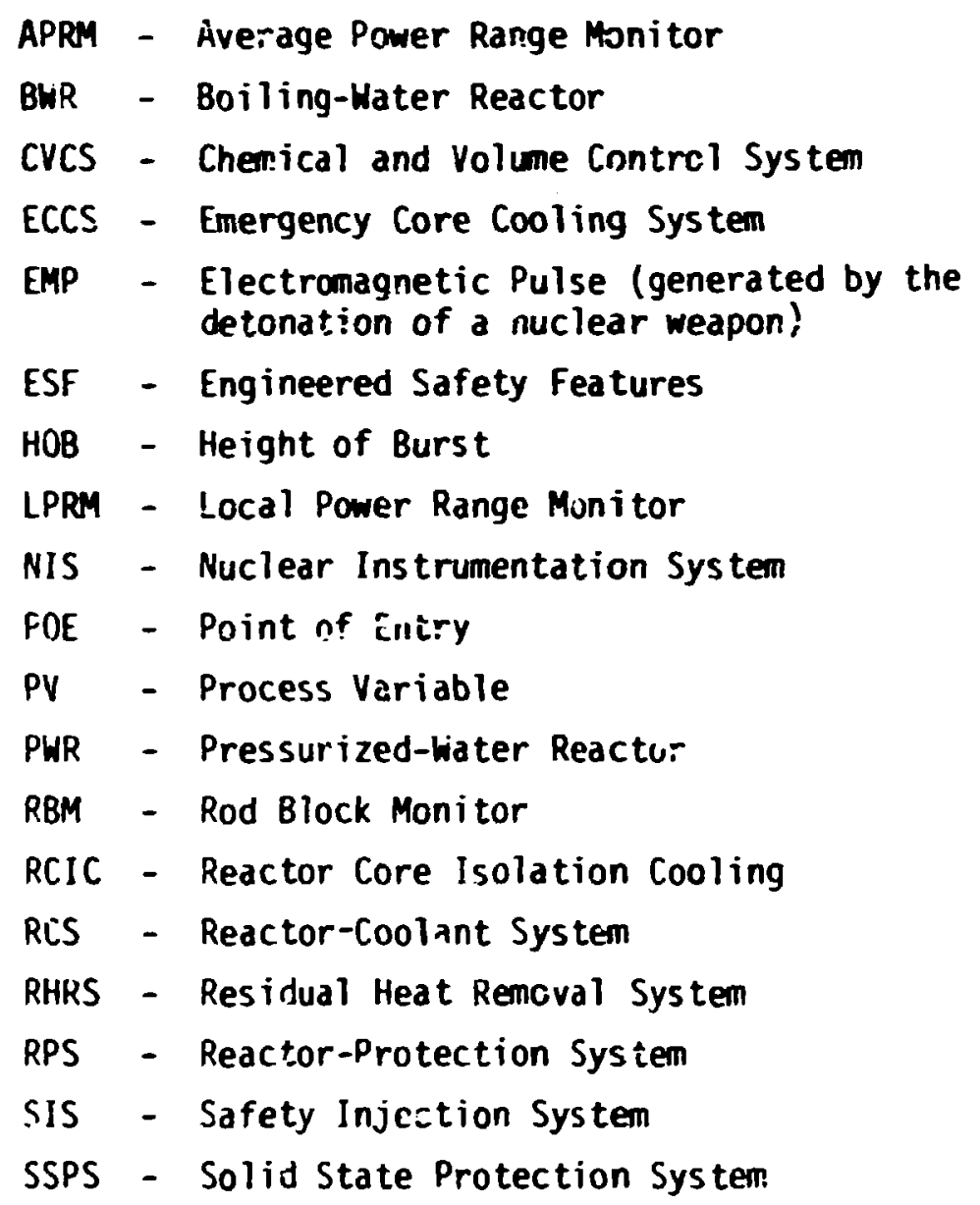




\section{THE EFFECTS OF NUCLEAR ELECTROMAGNETIC PULSE}

SEMP ON NUCLEAR POWER PLANTS

P. P. Barnes

R. H. Manweiler*

R. R. Davis ${ }^{\star *}$

\section{ABSTRACT}

The electromagnetic pulse (EMP) from a high-altitude nuclear detonation consists of a transient pulse of high intensity electromagnetic fields. These intense fields induce current and vol tage transients in electrical conductors. Although most nuclear power plant cables are not directly exposed to these fields, the attenuated EMP fields that propagate into the plant will couple some EMP energy to these cables. This report predicts the probable effects of the EMP transients that could be induced in critical circuits of safety-related systems. It was found that the most likely consequence of EMP for nuclear plants is an unscheduled shutdowr. EMP could prolong the shutdown period by the unnecessary actuation of certain safety systems. In general, EMP could be a ruisance to nuclear power plants, but it is not considered a serious ihreat to plant safety.

\section{INTRRDUCTION}

\subsection{Purpose and Content}

Nuclear power plants are designed to minimize the probability of accicents which would damage the plant or endanger the community. rrotection against accidents is normally provided by large safety factors in the design and use of redundant safety and instrumentation equipment. The redundant equipment provides protection against a single failure in the instrumentation and safety systems. This provides a large safety margin since the probability of a multiple failure involving two or more independent instrumentation channels or safety systems is considered to be extremely small. However, the probabiiity of a multiple failure due to EMP was not considered in the original safety analysis. This probability is not necessarily small since all parts of the system ray be subjected to the failure mechanisms at the same time.

*Ursinus College, Collegeville, Pennsylvania

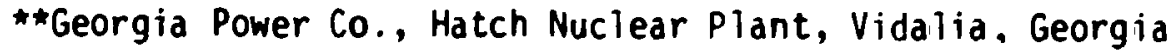


The purpose of this study is to determine if Emp is a serious problem for nuclear power plants and, if necessary, reconmend means of protecting these plants from potentially unsafe conditions. Due to the 1 imited scope of tinis effort and the complexity of the EMP power plant problem, zeroth or first-order estimates have been used to determine the EMP-induced transients and their probable eifects on the plant. if warranted, a more in-depth analysis can be pertormed in a later study.

The second section of this report briefly describes some of the more important systems in light-water nuclear power plants. The third section covers the expected Exp surges and their probable effects on importanic plant systems. The latter sections cover the consequences of assumed worst-case EMP effects for nuclear plants.

\subsection{High-Altitude EMP}

The detonation of a nuclear meapon is accompaniec by an EMP with a large portion of its energy within the radio frequency spectrum. The process by which EMP is generated is described in previous reports. ${ }^{1,2,3}$ The electromagnetic fields radiated from nuclear detonations vary greatly with weapon yield and detonation location. A strong EMP is produced by both hign- and low-altitude detonations. The EMP produced by a low-altitude detonation attenuates quickly with distance and is normally accompanied by the other nuclear weapon effects. High-altitude EMP is produced by a nuclear detonation at an altitude near or above $50 \mathrm{~km}$. Due to the large area of the Comptonelectron source current, high-altitude EMP can cover a large portion of the country which is completely free from the other nuclear weapon efferts. Nearly ail nuclear power plarics will be subjected to highaltitute EMP due to its wide area of coverage. Typical areas of coverage for a megaton-range weap in detonated at a height of burst (HOB) of $100 \mathrm{~km}$ and $400 \mathrm{~km}$ are shown in Fig. 1.1. As shown, most of the United States can be covered by a single exoatmospheric burst.

The stiort duration EMP fields are very intense. The amplitude of the electric field pulse is on the order of $50 \mathrm{kV} / \mathrm{m}$. The time history of EMP is characterized by a very short rise time of about in nanoseconds 


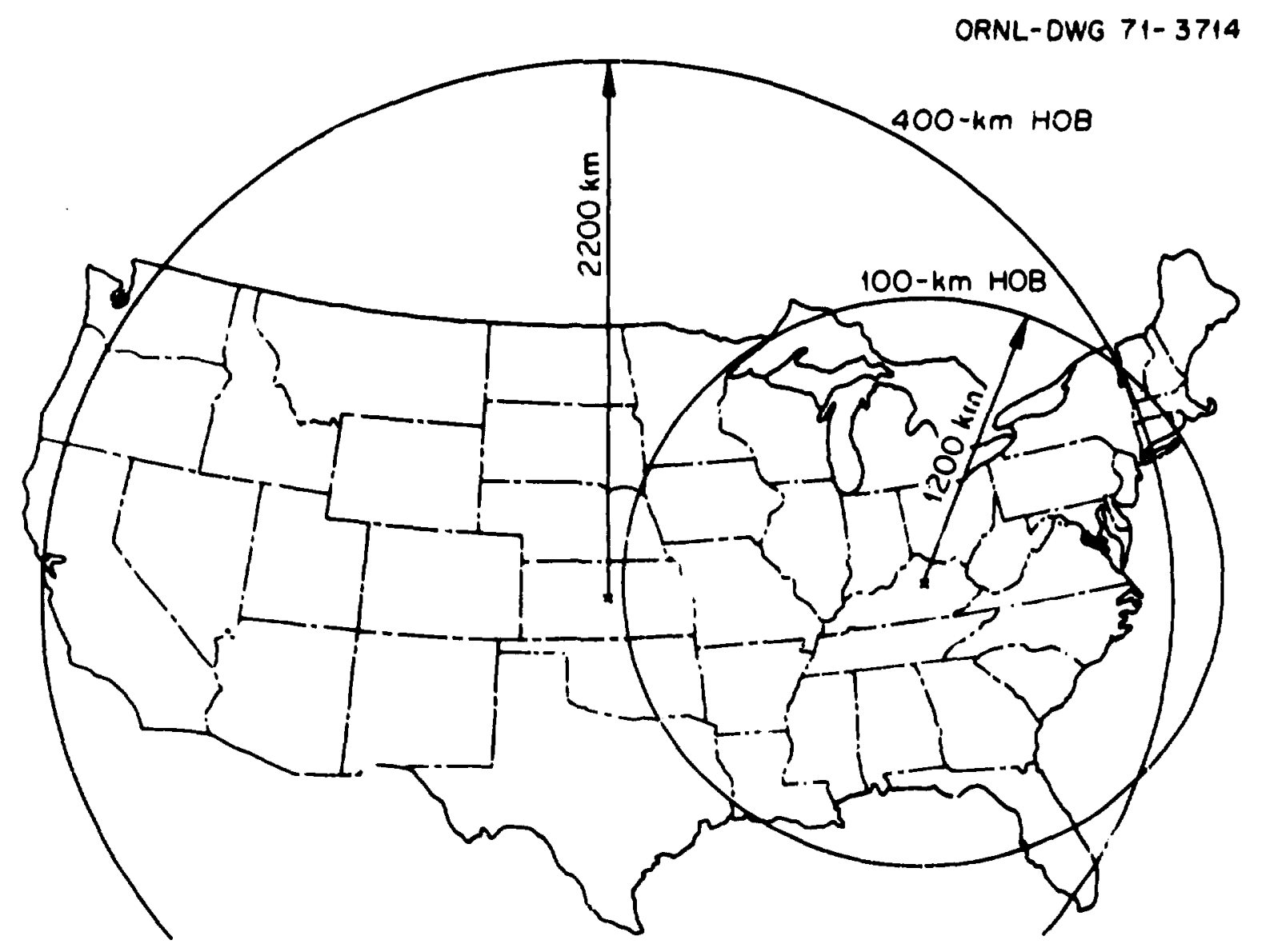

Fig. 1.1. Area of Coverage of EMP from High-Altitude Detonations. 
'nsec) and an exponential-type decay with a time constant on the order of $200 \mathrm{nsec}$. A double exporential is often used to describe the EMP wave form. An example of a double exponential EMP wave form is shown in Fig. 1.2. The fast rise time implies a wide excitation bandwidth, and the high intensity implies significant energy content in a broad range of the electromagnetic spectrum.

\subsection{The EMP Threat}

Any conductor exposed to the EMP fields performs as an inadvertent antenrad by receiling EMP eriergy. The EMP-induced electrical transients in conductors greater than $30 \mathrm{~m}$ (100 ft) long have large magnitudes comparab?e to near-average lightning surges. However, both the rise and decay times of EMP surges are much shorter than those of lightning suryas. Many solid state components are especially vulnerable to these fasi rising EMP surges. This is due to the significant energy at high freq.encies. The fast rising surges also present special protection problems.

The instrumentation, control, and power lines of a nuclear power plant will have EMP surges induced in them. Evr.n well shielded lines may pick up enough EMP noise to upset (change the state of) sensitive iugic circuits. Also, cumulative effects of EMP surges may cause damage to electronic components which might survive a single pulse. Multiple failures due to damiged components or upset circuits may cause the plant protection systems to respond incorrectly. To examine this possibiiity, we shall focus our attention on the instrumentation, control, and safety systems of modern nuilear power plants.

\section{MODERN NLICLEAR POKIER PLANTS}

\subsection{Introduction}

The basic elements of a modern nuclear power plant are shown in Fig. 2.1. The reactor is the source of heat energy which is transferred to the heat excianyer by the reactor-coolant systems (RCS). The reactor 

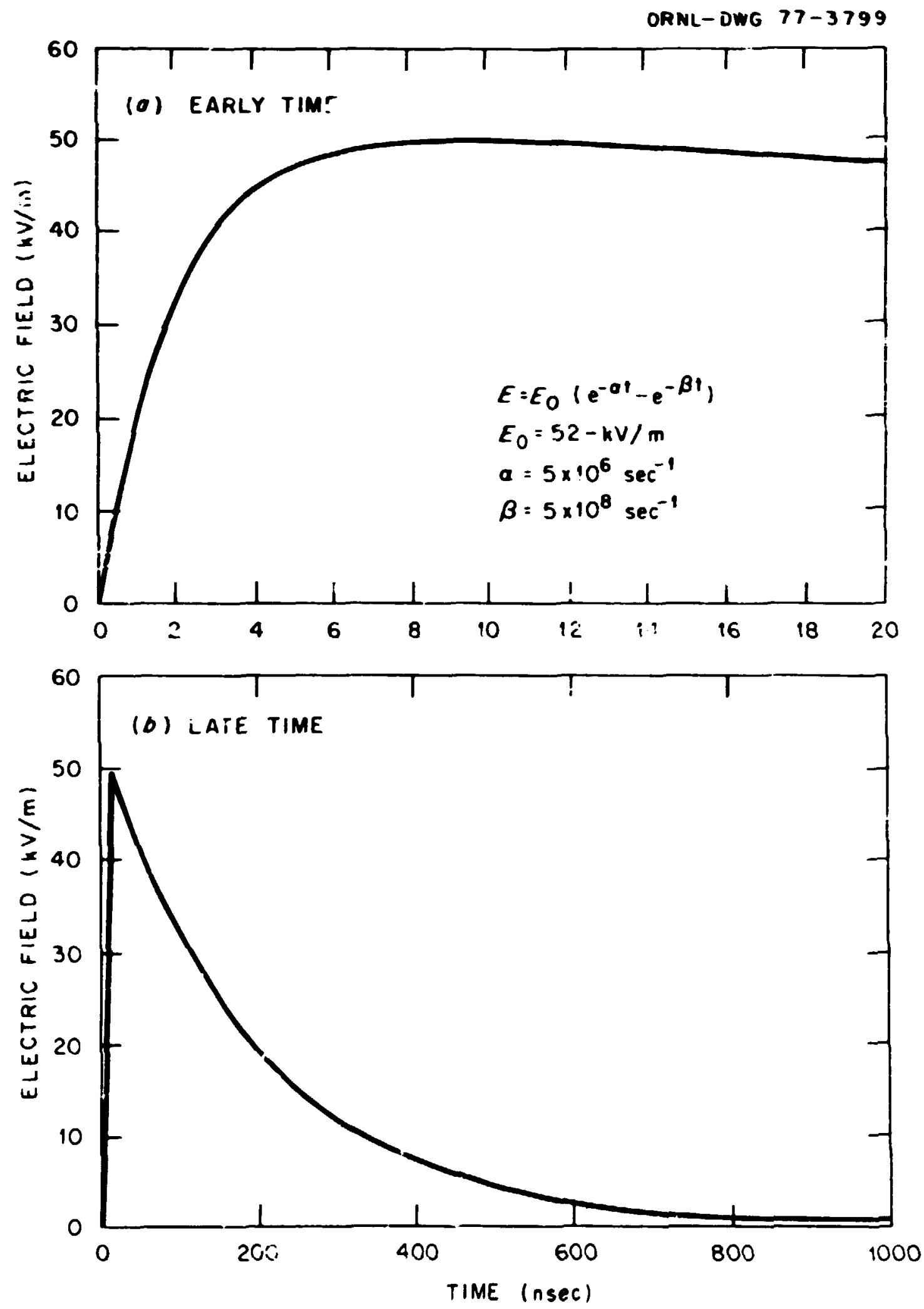

Fig. 1.2. Double Exponential Wave Form used to Represent the EMP Electric Field Time History. 


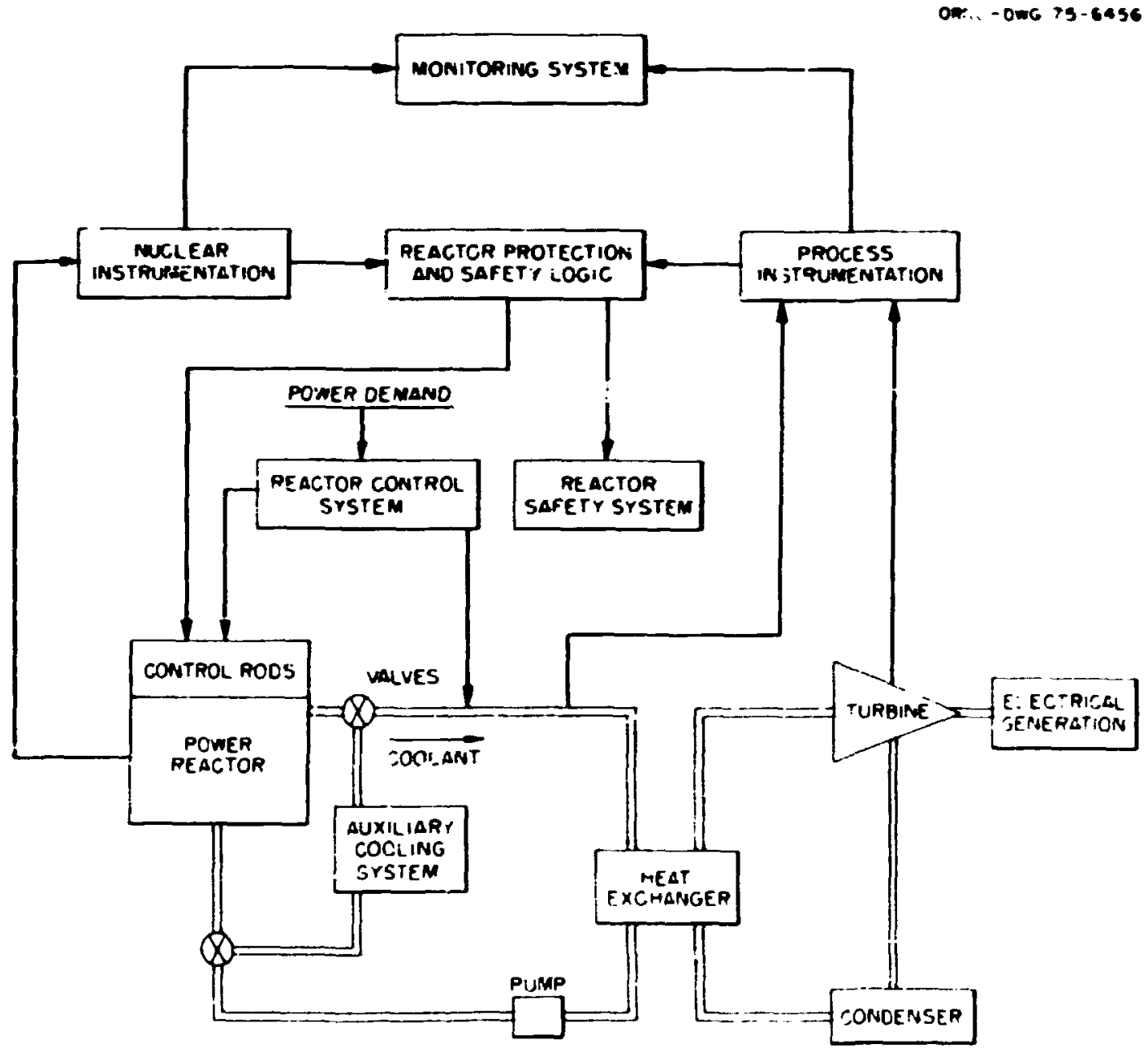

Fig. 2.1. Simplification Block Diagram of a Nuclear Power Plant. 
coolant deternines the reactor type; i.e., water is used in PressurizedWater Reactors (PWR's), water and stean are used in Boiling-Water Reactors (BUR's), and gas is used in high-temperature, gas-cooled reactors. The heat exchanger serves to restrict the radioactivity to the reactor and the reactor-coolant system. The turbine, condenser, and electrical generator operate in a similar manner as those in coal-or oil-fired power plants.

Also show in the diagram are the reactor control and safety systems. The reactor-coritrol system can control the power output of the reactor by proper positioning of control rods lccated in the reactor core and by adjusting reactor-coolant parameters. The operator can monitor the plant operation by a monitoring system which recsive:; inputs from the nuclear and process instrumentation systems among others. The nuclear instrumentation system monitors the neutron flux in the reactor, and the process instrumentation system monitors the temperature, pressure, and flow rate of the reactor coolant. The nuclear and process instrumentation systems are part of the reactor-protecticn system (RPS) which, if necessary, can scram (shidt down) the reactor and initiate special reactor safety winsures.

Not shown in Fig. 2.1 are the various essential electrical power systems. Control, instrument, and ac electrical cower are all important for the safe operation of the plant. Most reactor safety systems also require electrical power. Since it is possible that normal power can be incerrupted, backup power is normaliy provided for these systems.

The nuclear power plants now operating or under construction in the United States are PWR and BWR plants. We shall focus our attention on these two important nuclear plant types.

\subsection{Pressurized-Water Reactors}

Modern pressurized-water power reactors have iwo reactor-coolant loops separated by a heat exchanger as shown in fig. 2.1. ${ }^{4}$ The primary loop removes heat direcily from the reactor. The secondary loop provides steam to drive the main turbines. In large reactors such as the 1200-MW(e) PWR used in the Sequoyah nuclear plant near Chattanooga, 
Tennessee, the primary loop system consists of four essentially identical coolant loops. 5 Pressurized water is circulated in each of the four loops from the reactor vessel io a stean gererator (heat exchanger) by a 6000 -hp coolant pump. A single pressurizer in one loop maintains the required coolant pressure for all four loops. Chemical control of the coolant is provided by the chemical- and volume-control system (CVCS). The CVCS also maintains the correct water level in the pressurizer and provides the izquired coolant pressure when the RCS is cold.

Magnetic-jack control-rod-drive mechanisms die used to position the PUR control rods. These drive mechanisms are located above the reactor vessel. During normal plant operation, the drive mechanisms hold in position the control rods that have been withdrawn from the core. If power to the magnetic jack is removed, either deliberately by a reactor trip or because of an accidental power loss, the control rods fall instantly by gravity into the core. ${ }^{4}$

Important safety-related PWR auxiliary systems are the residual heat removal system and the engineered safety features. The residual heat removal system (RHRS) consists of dual heat exchangers and pumps. The purpose of the RHRS is to remove heat from the core during plant shutdown. The RHRS is also part of the emergency core cooling system (ECCS) which has the function to supply cooling water to the reactor under accident conditions. The RHRS is normally activated about four hours after the control rods have been inserted into the core.

The engineered safety features (ESF's) include the safety injection. system and the containment spray system among others. The safety injection system is part of the ECCS. It supplies borated water to the reactor to ensure that the reactor remains shut down after a loss-ofcoolant accident.

\subsection{Boiling Water Reactors}

The core design of a BWR is such that the water coolant is allowed to boil in the active region of the system. ${ }^{6}$ The steam is directiy cnanneled to the turbine for electrical power generation. Thus, there 
are no secondary loops in a modern BuR steam supply system. Figure 2.2 shows a simplified schematic representing a direct-cycle, forcedcirculation BUR with the major control systems incorporated.

Dependiny upon the power level of the reactor, the boiling rate can tend to ccmpromise the effectiveness of the water moderator. Bo:iing bubbles are forne around the circunference of the fuel rods. As the conceitration of bubbles increases, rewer neutrons are reflected back into the fuel rods to continue the chain reaction at its desired rate; thus, the reaction der.reases with a subsequent decrease in the reactor power level. Because of this phenomenon, the modern boiling-water reactor incorporates jet pumps into the recirculation flow loop. The purpose of these pumps is to control the bubble concentration and thus control the available reactivity and hence the power without movement of the control rods. Approximately two-thirds of the recirculation flow in the reactor vessel is generated by these jet pumps. In practice, the power level may be altered as much as $25 \%$ by this technique.

The BAR control rods are mounted on the bottom of the reactor vessel and are positioned by hydraulically actuated piston-drive mechanisms. The drive mechanisms can position the coritrol rods at increments over the entire core length. The Jrive mechanisms can also scram the reactor by driving all of the rods into the core. The scram signal overrides all oiner control signals to the tri,e mechanisms.

Important safety-related BWR auxiliary systems i re the reactor core isolation cooling system (RCIC), the ECCS, and the RHRS. he RCIC supplies cooling water to the reactor in the event the vessel is isolated from the turbine steam line and from the feedwater flow. The BWR ECCS consists of high-and low-pressure core spray systems and the various modes of RHRS. The RHRS is made up of various subsystems including the low-pressure coolant injection system, suppression fool cooling system, and the shutdown cooling system. The shutdown cooling system removes low-level residual reactor heat. It is normally initiated about 20 hours after shutóown. 


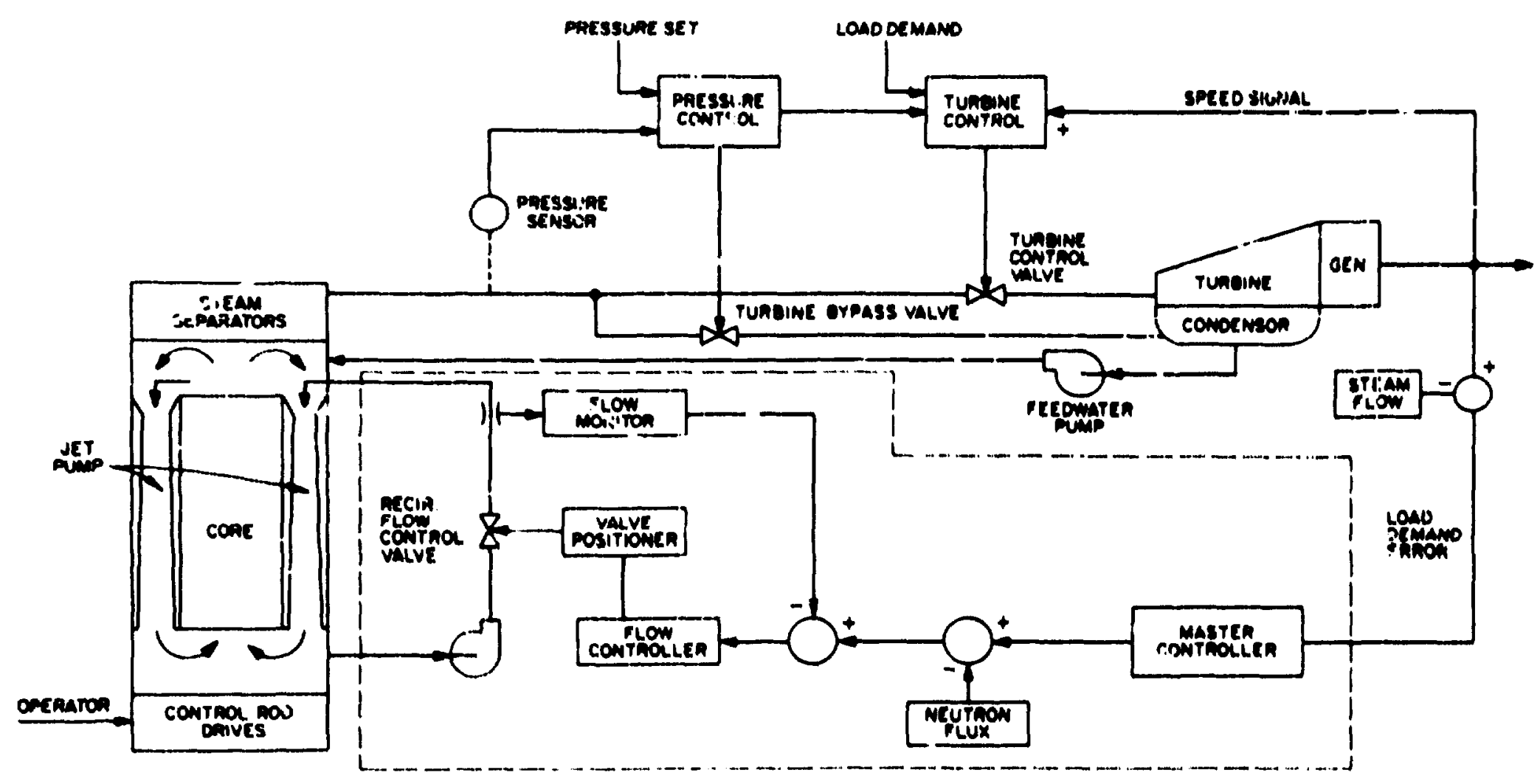

Fig. 2.2. Simplified Blnck Diagram of the Direct Cycle BWR with Major Control Sys tems. 


\subsection{Instrumentation and Controls}

OARE: nuclear power plants have sophisticated instrumentation and conis:s. "iple instrumentatior. and control channels are used 0 pre... s stem failures due to a single maifunction. The nuclear instrumentation system (NIS) monitors the neutron flux, its spatial slope in the core, and its rate of change. The process instrumentation typically monitors the temperature, pressure, and fiow rate of the primary and secondary coolant systems. Various spatial and time derivatives are aiso monitored by the process yariable (PV) instrumentation.

The instrumentation systems noitially employ low-level-current analog signal trinsmission from the sensors to the instrumeritation racks. Industry standards for process instrumentation signal curr ents are 4-20 $\mathrm{mA}$ and 10-50 $\mathrm{mA}$. Nuclear instrumentation signa? currents are normally one or more milliamperes. The signal-current range used in Westinghouse PWR's is 0-4 mA.

Due to the low signal ievels, sensor cables are generally well shielded against electromagnetic noise. The NIS cables may also be placed in conduit for electromagnetic noise suppression and physical protection.

The primary purpose of the instrumentation is to provide information for the RPS and for the operator. Digital informa: : on which indicates that the engineering desig, limits have been exceeded is provided to the RPS logic by bistables which change stites when cartain in-trumented variables or their derivatives exceed or fall below preset valuas. This is rormally accomplished by removing the voltage at the input of the RPS logic. If the RPS logic input is de-energized by a failure in the instrumentation system or the interruption of instrument nower, a bistable trip signal is generated. Tinus, the system is sain tc be fail-safn. The bistables that are typically used in nuclear power plant instrumentation return to their origina! state once the trigger signal is removed. An exception to this is the latchirg bistable which changes state and remains in the new state until the circuit is reset. 
The cont: ol systen controls reactor power, reactor coolant variables such as temperature, pressure, etc., and the turbine generator output. Reactor nower is controlled by moving the control rods or adjusting coolant variables. The controi system utilizes relatively high signal voltages on the order of $120 \mathrm{~V}$ or greater tc activate rod, valve, and pump controis. Electrical noise is generally not a problem at these signal levels.

The operator is furnished with information on the plant status by the monitoring system. Positions of control rods, nuclear and process instrumentation var iables, as well as many other variables, are monitored. Modern monitoring systems employ a computer to provide continuous plant status information.

\subsection{Plant Electrical Power}

The plant electrical power systems are the off-site auxiliary power, the nuclear-unit auxiliary power, emergency auxiliar' power supplied by diesel-driven generators, and the inverter-charger battery supplies. The auxiliary power voltage is nomally several kilovolts. (Typical auxiliary power voltages are 4000 volts or 6900 volts.) This voltage is used to powel the large motors throughout the plant. Lower voltages such as 400 volts, 240 volts, and 120 volts are obtained from stepdown transformers to power small motors and other plant auxiliary loads.

The loss of the off-site auxiliary power will often scram (shut down) the reactor. The auxiliary systems essential to a safe shutdown are then transferred to the diesel generators. Important iristrument and control power is maintained by the battery-inverter power supplies for several seconds until the diesel generators obtain the proper voltage.

\section{EMP SYSTEMS ANALYSIS}

\subsection{Approach}

The general dpproach for an EMP systenis analysis is to (1) identify the important systems, (2) determine the points of entry (POE's) through 
which IMP energy can enter each system, (3) obtain quantitative estimates of the EMP surges at the POE'S, and (4) determine the probable effects of these surges on each systen. Due to the numeror.s systens and the complexity of a nuclear plant, a very detailec and exact analysis is beyond the scope of this effort. A more complete and thorough analysis should be performed at the conclusion of this study on those systems that appear to have EMP susceptibilities. This should presumably be done by the various systens' mar.ufacturers.

The important systens of interest in nuclear power plants are those related to reactor and plant safety. Thase are the instrimentation systems, the reactor protection system, the reactor control system, the monitoring system, the residual and emergency heat removal systems, and essential electrical power systems.

The EMP energies which can couple to systems by the plant electrical ground system are minimized by installation practices which avoid ground loops in order to reduce electrical noise effects. The electromagnetic fields that can intera:t directly with the systems' electronics are greatly reduced by the attenuation afforded by the metal cases and grounded metal equipment racks. The most important EMP coupling mechanisms for most of the systems and equipment in the plant are the cables and wires that are connected to the systems.

The expected EMP surges on power plant cables have jeen in restigated by a previous study. ${ }^{i}$ These surges vary greatly and depend on the location, shielding levels, and length of each cable. Thus, the surges are dependent on parameters which can vary from plant to plant. We have assumed that the shielied cables are similar among plants of the same type. For cable lengths and locations, we have assumed realistic worst-case conditions. To obtain these parameters, the Sequoyah nuclear plant has been used as a model of a modern PWR plant, and the Browns Ferry nuclear plant in Alabama, and the Hatch nuclear plant in Georgia have been used as modern BWR plants.

To evaluate the possible effects of EMP on the important systems, the peak F.MP surge is compared with the normal operating level on each cable connected to the systems. If the surge peak is ten times greater 
than normal levels, then damage is possible and may occur. If the surge peak is equal to the setpoint of trigger circuits for a sufficient duration, then a logical upset or change-of-state may occur.

\subsection{EMP Surges}

The EMP surges induced in electrical transmission lines and nuclear power plant cables have been considered in previous studies. 7,8 The anplitudes of the induced surges depend on the EMP wave form, the length of cable or line, the orientation of the cable with respect to the incident EMP and the earth, and the level of electromagnetic shielding. For our analysis, we shall take the conservative approach by assuning worstcase EMP coupling conditions. Worst-case EMP coupling conditions are those that realistically maximize the EMP surges.

Electrical power transmission lines will collect large amounts of EAP energy due to their length. The EMP voltage surges will have peaks on the order of a megavolt with rise times on the order of a tenth of a microsecond. These surges will occur on all of the lines througiout the power grids. Flashovers on these lines and in the switchyards will likely initiate circuit breaker action to disconnect the preferred offsite plant power. Also, the entire power grid is likely to become unstable, if subjected to multiple EMP's, resulting in a power blackout. ${ }^{9}$ Thus, EMP is likely to cause a loss of the preferrod off-site piant power.

Realistic worst-case EMP surges on the off-site power lines at the plant transformer are shown in fig. 3.1. ${ }^{7}$ The voltage peak is over $9 \mathrm{MV}$. The iransient decays to near $1 \mathrm{MV}$ after $10 \mathrm{\mu sec}$. Most high-voltage transmission lines would probably flashover and significantly reduce the surge amplitude. However, if flashover does not occur, a portion of the surge will capacitively couple across the plant transformer. Typical transformers have a primary-to-secondary winding capacitznce of several hundred picofarads and a secondary-to-earth capacitance of several nanofarads. The transformer appears as a capacitive voltage divider to the transients; and the voltage transients, coupled to an "open-circuit" secondary, have the same wave form as that in fig. 3.1 


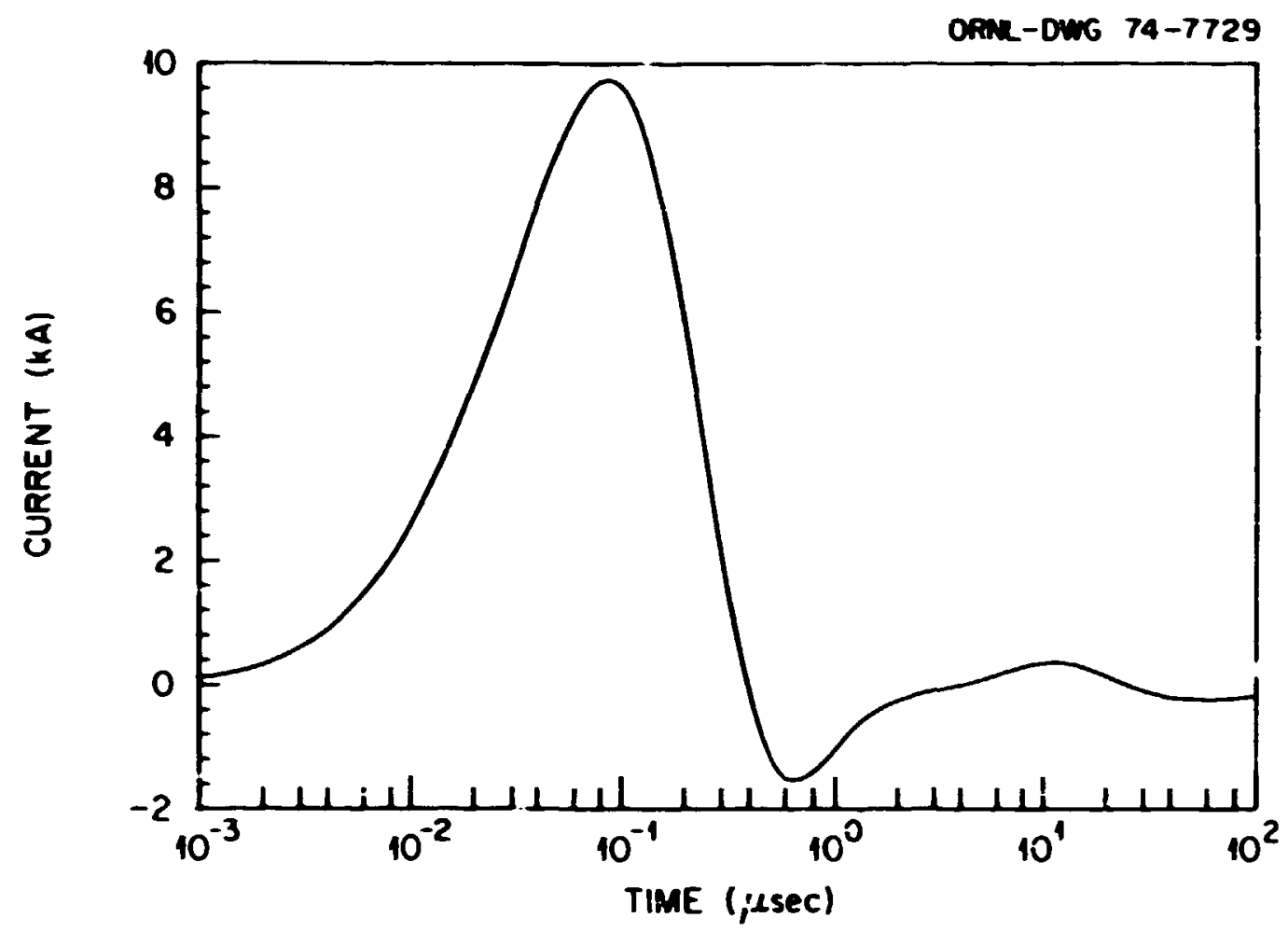

(o) CURRENT SURGE

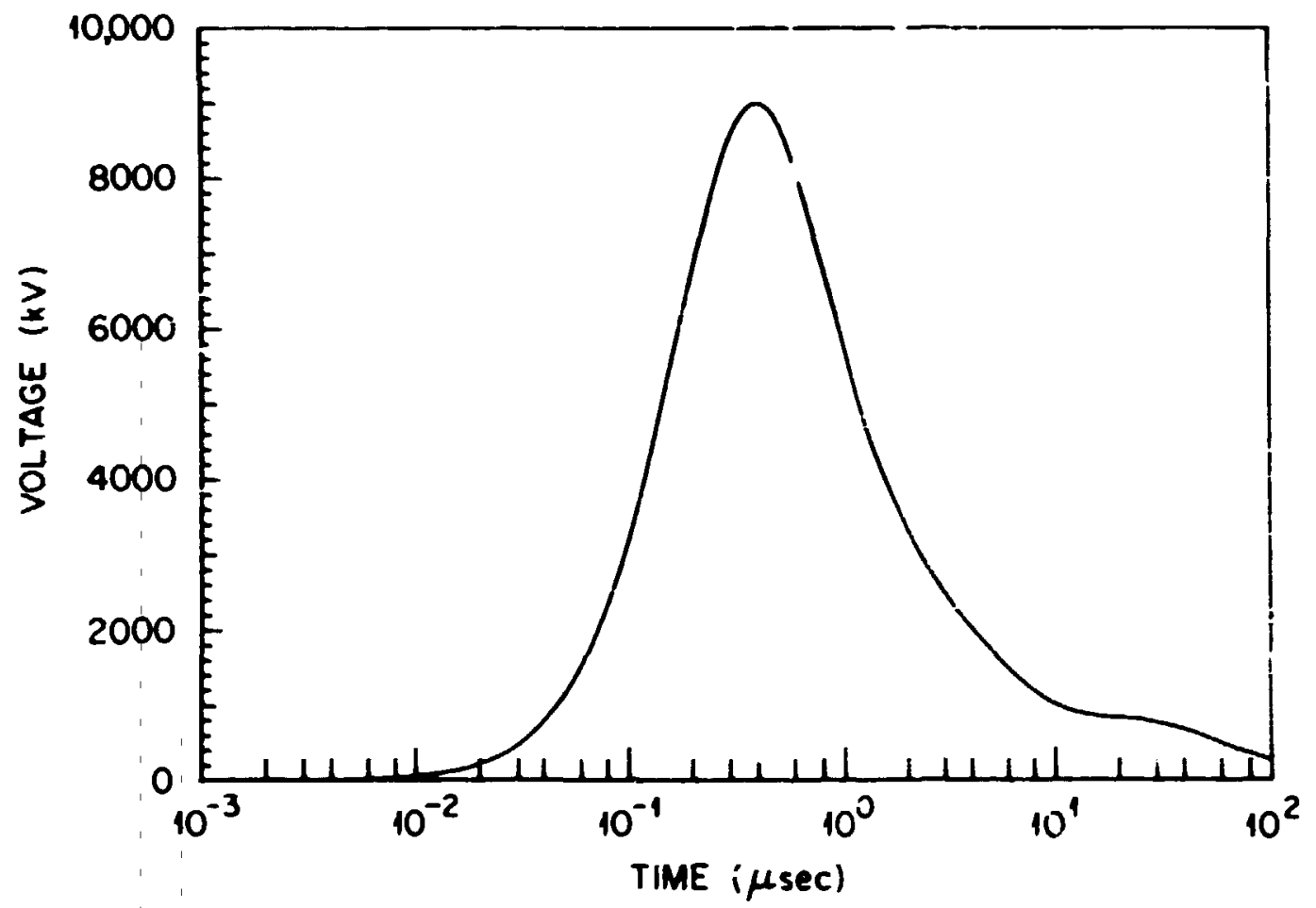

(b) VOLTAGE SURGE

Fig. 3.1. EMP Surges at the Plant Off-Site Power Transformer. 
except that the amplitude is reduced by about a factci of five. The per-phase-load resistance of a nuclear plant is abolic one ohm. Thus, the time constant of the secondary winding capacitance and the one-ohm load is several nanoseconds.

The surge coupled to the secondary side of the plant power transformer will decay to near zero after 10 nsec. This short-duration pulse will not likely cause a flashover since air normally requires more time to ionize. The total energy dissipated by the one-ohn load is less than one kilojoule. This energy should not do any damage to the relatively high voltage and high-current power circuits.

The EMP surges induced in the numerous cables within the plant building have been considered in a previous stucy. 7 The types of cables considered wore unshielded wires, coaxial and triaxial cables, and shielded twisted pairs. Long cables located near an exterior wall will collect more Emp energy than cables located elsewhere in the plant. Cables located in conduit or in cable trays collect less EMP energy than single cables. In Figs. 3.2 and 3.3, the EMP surges induced in an unshielded wire and a coaxial cable are shown for $160-m$ cables routed along an exterior wall. These surges may be considered as upper-bound or worst-case surges.

The EMP surges that will be iriuced in the various plant cables are shown in Table 3.1. Since the lengths of cables interconnecting the many plant systems vary from plant to plant, we shall assume that all cables are relatively iong, near $160 \mathrm{~m}$. This gives conservative results for the EMP surges listed in Table 3.1.

\subsection{Plant Noisa and Transient Protection}

Many systems in a nuclear power plant are designed to operate courectly in an environment of electrical and electromagnetic transients. These transients are due to the many electromechanical relays, motors, and circuit switches in tne plant. io ensure the operation of instrumentation, contral, and safety equipment, a relatively hign levei of noise and transient protection is employed. Much of this protection provides a high levei of inherent hardness against EMP surges. 

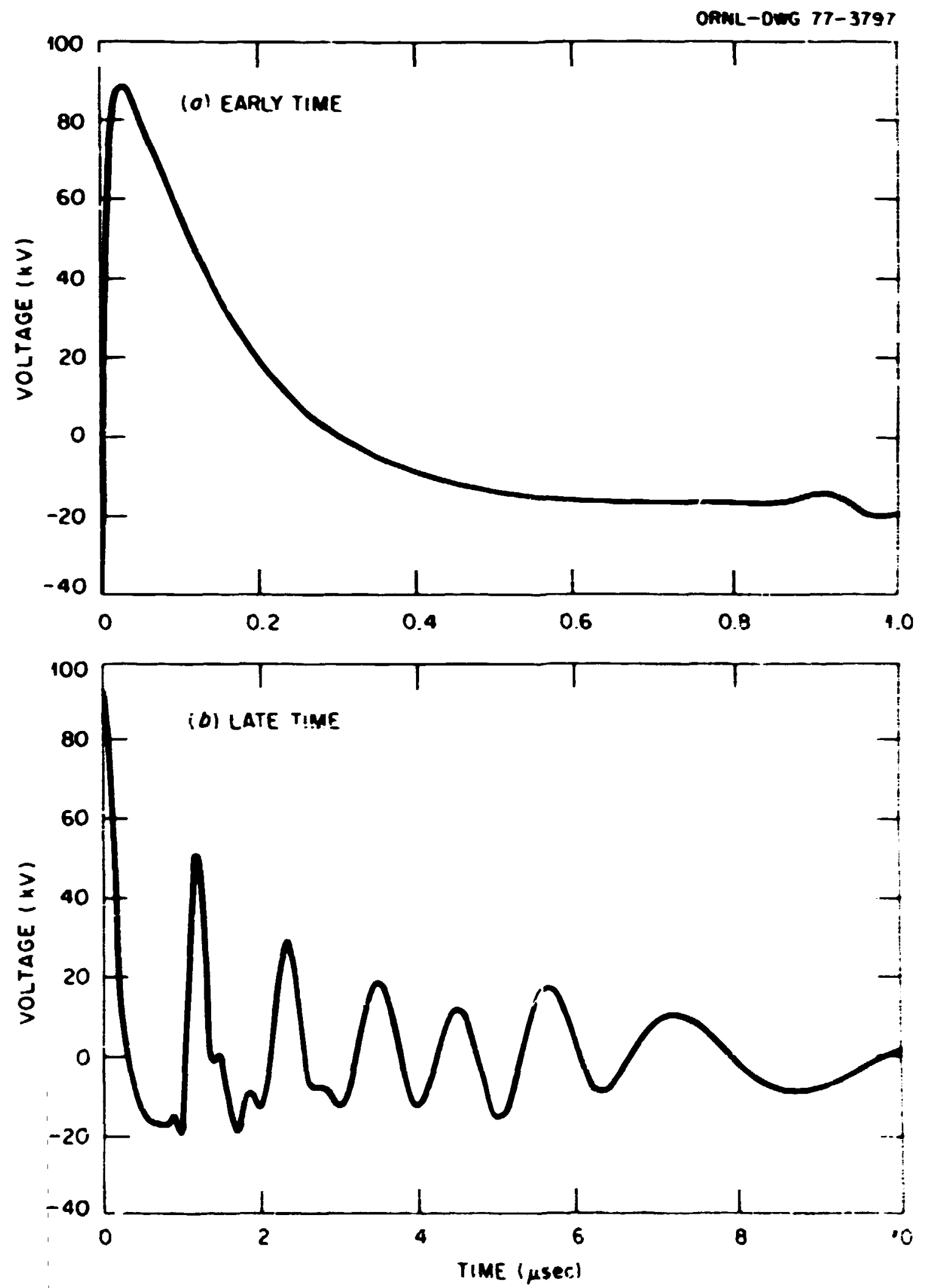

Fig. 3.2. The Open Circuit Voltage Induced on a $160-\mathrm{m}$ Unshielted Line $10 \mathrm{~m}$ aboye the Earth by the Representative EMP. 

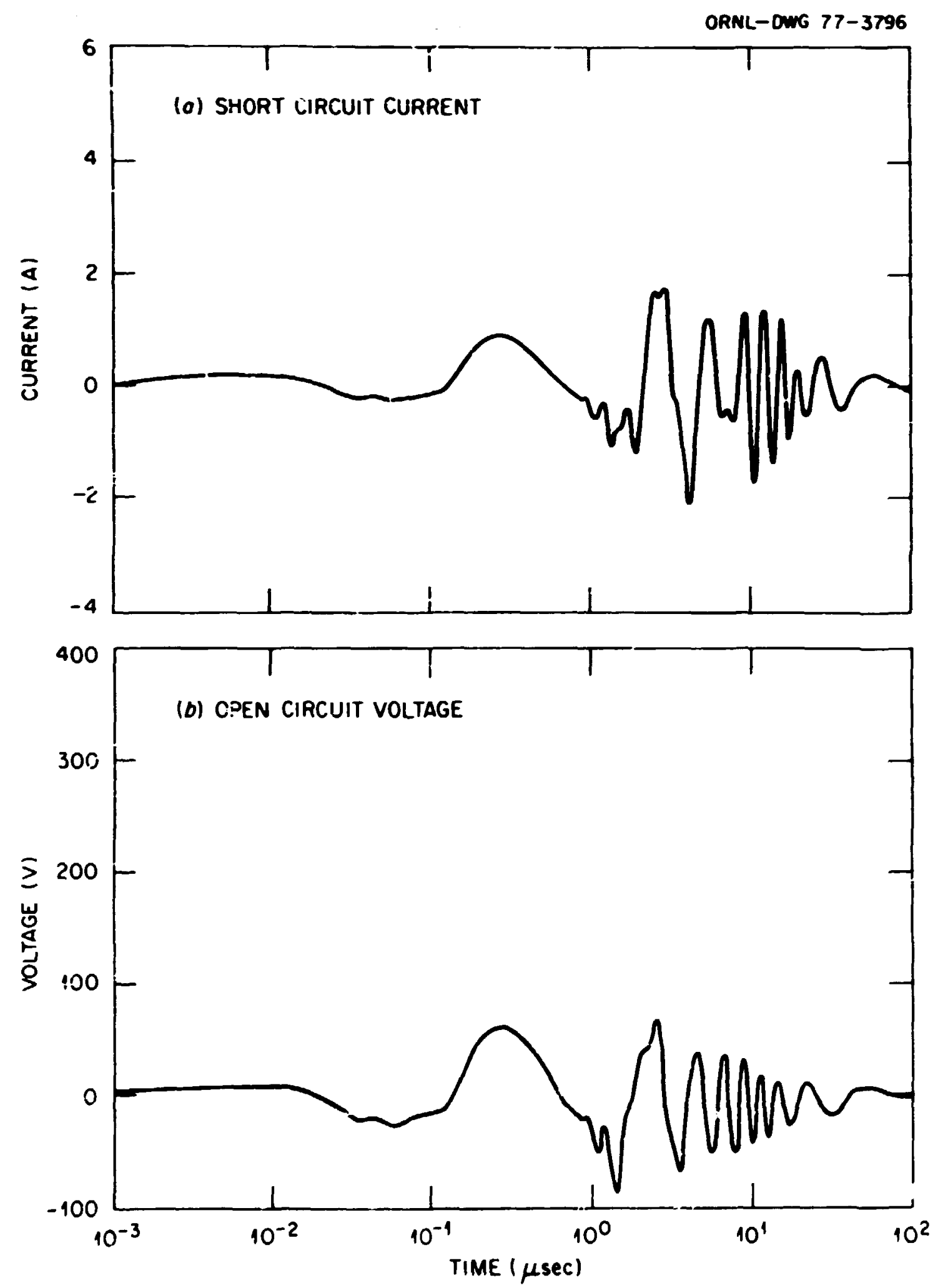

Fig. 3.3. Open Circuit Voltane Transient Induced in a 160-m Coaxial Cable Similar to RG-59B/u. 
Table 3.1. EMP Cable Surges

\begin{tabular}{|c|c|c|c|c|c|}
\hline Caible & Location & $v_{p}$ & ROR & Duration & $I_{p}$ \\
\hline $\begin{array}{l}\text { Unshielded Copper } \\
\text { Wire }\end{array}$ & Near an External Wall & $88 \mathrm{kV}$ & $7.12 \mathrm{kV} / \mathrm{nsec}$ & $6.4 \mu \mathrm{sec}$ & $170 \mathrm{~A}$ \\
\hline $\begin{array}{l}\text { Unshielded Copper } \\
\text { Wirs. }\end{array}$ & $\begin{array}{l}\text { Near an External Wall } \\
\text { in a Cable Tray }\end{array}$ & $8.8 \mathrm{kV}$ & $710 \mathrm{~V} / \mathrm{nsec}$ & $50 \mu \mathrm{sec}$ & $17 \mathrm{~A}$ \\
\hline $\begin{array}{l}\text { RG-59B/U Coaxial } \\
\text { Cable }\end{array}$ & $\begin{array}{l}\text { Near ar External Wall } \\
\text { in a Cable Tray }\end{array}$ & $8 \mathrm{kV}$ & $0.1 \mathrm{~V} / \mathrm{nsec}$ & $10 \mathrm{msec}$ & $0.22 \mathrm{~A}$ \\
\hline Triaxial Cable & $\begin{array}{l}\text { Near an External Wall } \\
\text { in Conduit }\end{array}$ & $37.5 \mu V$ & $15.6 \mu V / n s e c$ & $10 \mathrm{~ms} / \mathrm{c}$ & $0.5 \mu A$ \\
\hline $\begin{array}{l}\text { Shielded Twisted } \\
\text { Pair }\end{array}$ & $\begin{array}{l}\text { Near an External Wall } \\
\text { in a Cable Tray }\end{array}$ & $0.8 \mathrm{~V}$ & $10 \mathrm{mV} / \mathrm{nsec}$ & $50 \mu \mathrm{sec}$ & $22 m A$ \\
\hline $\begin{array}{l}\text { Shielded Twisted } \\
\text { Pair }\end{array}$ & Near an External Wall & $8 V$ & $100 \mathrm{mV} / \mathrm{nsec}$ & $50 \mu \mathrm{sec}$ & $220 \mathrm{~mA}$ \\
\hline $\begin{array}{l}v_{p}=\text { Peak open cir } \\
I_{p}=\text { Peak short cil }\end{array}$ & $\begin{array}{l}\text { voltage } \\
\text { current }\end{array}$ & \multicolumn{4}{|c|}{$\begin{array}{l}\text { ROR = Initial rate of rise from io to } 90 \% \text { of } \\
\text { the open circult voltage } \\
\text { Duration = lime required for the voltage surge } \\
\text { to decrease to } 10 \% \text { of } v_{p}\end{array}$} \\
\hline
\end{tabular}


The noise and transient protection measures that are normally emplcyed include ore or more of the fcllowing: (1) shielded cables, (2) relatively high current and voltage signais, (3) relay isolation, (4) diode transient suppressors, (5) capacitive transient suppressors, (6) electrostatically shielded transformers, (7) isolation amplifiers, (8) filters to reject noise and transients, and (9) the response time required for actuation is long compared to most transients. Combifiations of these protective measures such as shielding, diode transient suppressors, and relay isolation will provide excellent EMP protection.

The plant electrical power circuits are protected against lightning by arresters at the station transformer and by the inherent lightn'ing shielfing capabiiities of the plant buildings. Power circuits are protected against fault currents by circuit breakers and differential relays. Surge suppressors are often installed on large motors to suppress 1 ine transients.

The noise and transient protection normally used in a nuclear plant have to be considered in the analys is of EMP surge effects on the instrumentation, control, and safety systems. Most of the protection measures employed provide adequate EMP protection. However, some lightning protective measures such as overhead ground wires and the shielding effects of the builuis:g may not provide effective EMP protection.

\subsection{Instrumentation and Control Systems}

The instrumentation and control systems consist of the process variabie (PV) instrumentation, the nuclear instrumentation system (NIS), the rod control system (RCS), and the reactor protection system (RPS). There are, of course, other instrumentation and control systems associated with a nuclear power plant. However, we have selected only those systems reicted to reactor safety for the analysis. Other systems and their instrumentation and controls which are related to reactor safety will be covered later in this section. 


\subsubsection{PijR Instrumentation and Controls}

The instrumentation, control, and protection systenis associated with the Mestinghouse PUR nuclear steam supply system cor: st of thi NIS, PV instrumentation, the RCS, and the solid-state protection system (SSPS). The SSPS consists of two logic trains which perform the logic (decision making process) for the RPS. A simplified block diagram of the SSPS is shown in Fig. 3.4. The RPS is composed of the instrumentation that monitors the reactor parameters, the SSPS, and various protection functions.

The NIS receives inputs from the four detectors located at each quadrant of the reactor core. A simplified block diagram of the ils is shown in Fig. 3.5. Detector signal current ranging fiom 0 to $4.1 \mathrm{~mA}$ is transmitted by triaxial RG-11/U rable to the NIS racks which are normaliy located in the control room. The detector cable is run in conduit the entire length from the containment to the control room. Due to the extensive amount of shielding afforded by the triaxial cable and the conduit, the maximum EMP-induced surge peak is only about $0.5 \mu \mathrm{A}$. This small current should have little effect on the system.

The NIS output cables are also shielded cables such as the twisted shielded pairs of wires used at the Sequoyah plant. Most of the input and output cables connected to the SS'S, PV instrunentation, and the RCS are also shielded cables such as shielded twisted pairs. These cables are normaliy placed in cable trays. The EMP transient voltage peak for a shielded twisted pair in a cable tray with several other cables is about $0 . \mathrm{o}^{\mathrm{V}}$. This 'iw-voltage transi:nt should have little or no effect on the instrumentation and control systems since the operational signals are much larger, ranging from 10 to $118 \mathrm{~V}$.

A small amount of surge energy in each of the input and output lines will couple across the relays to the $2 C S$ control logic circuits. Will EMP cause the control rods to be withdrawn? This quastion has been raised by those concerned about reactor safety. I' is unlikely that the EMP energy available could cause logical upsets (change of logic states) in the RCS logic. If we assume for the moment that iuch upsets du occur and that one or more rod clusters are accidentally 
ORNL-OWG 75-6453

TO CONTROL

RON SYSTEM

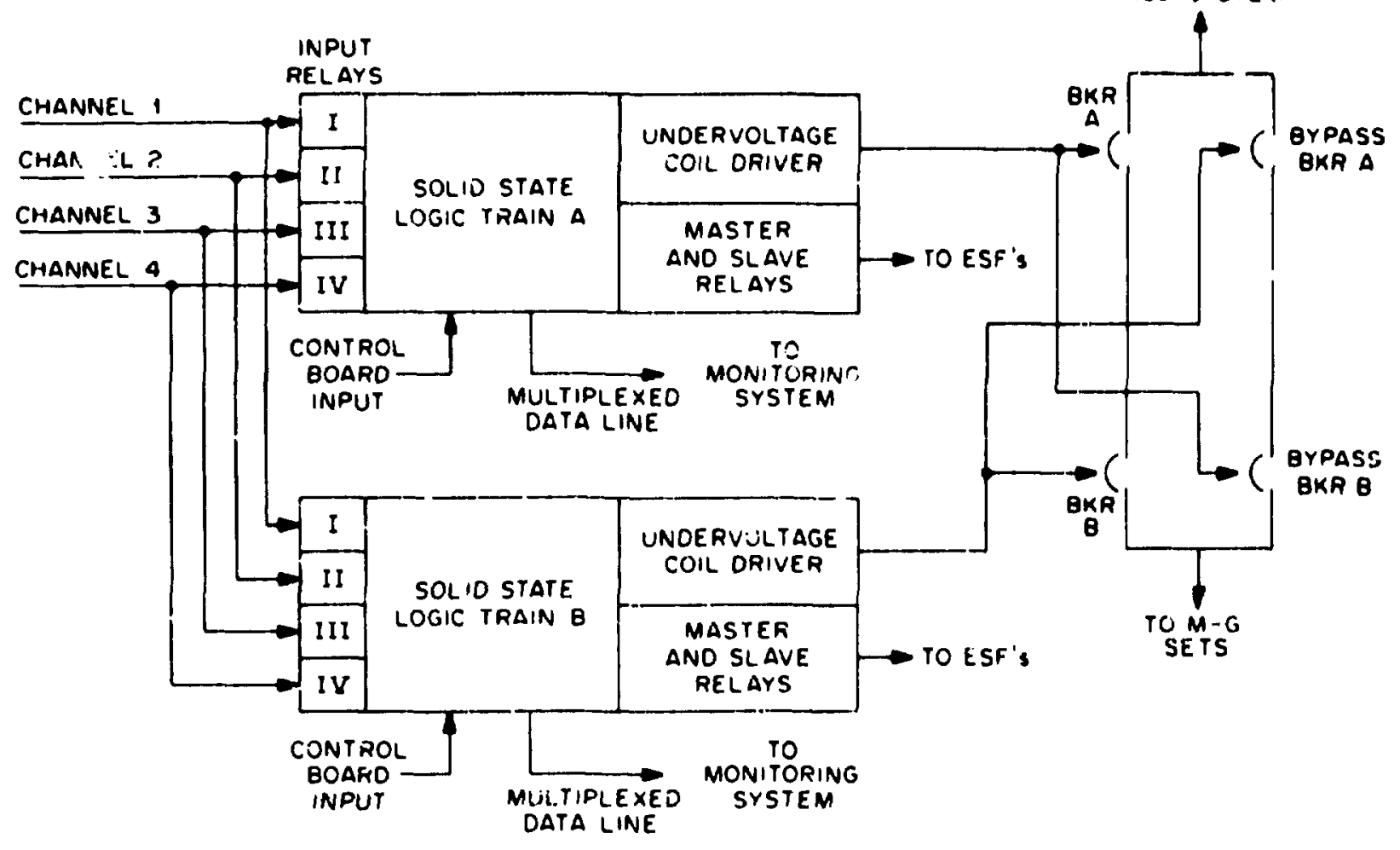

Fig. 3.4. Simplified Block Diagram of the Solid-State Protection System. 


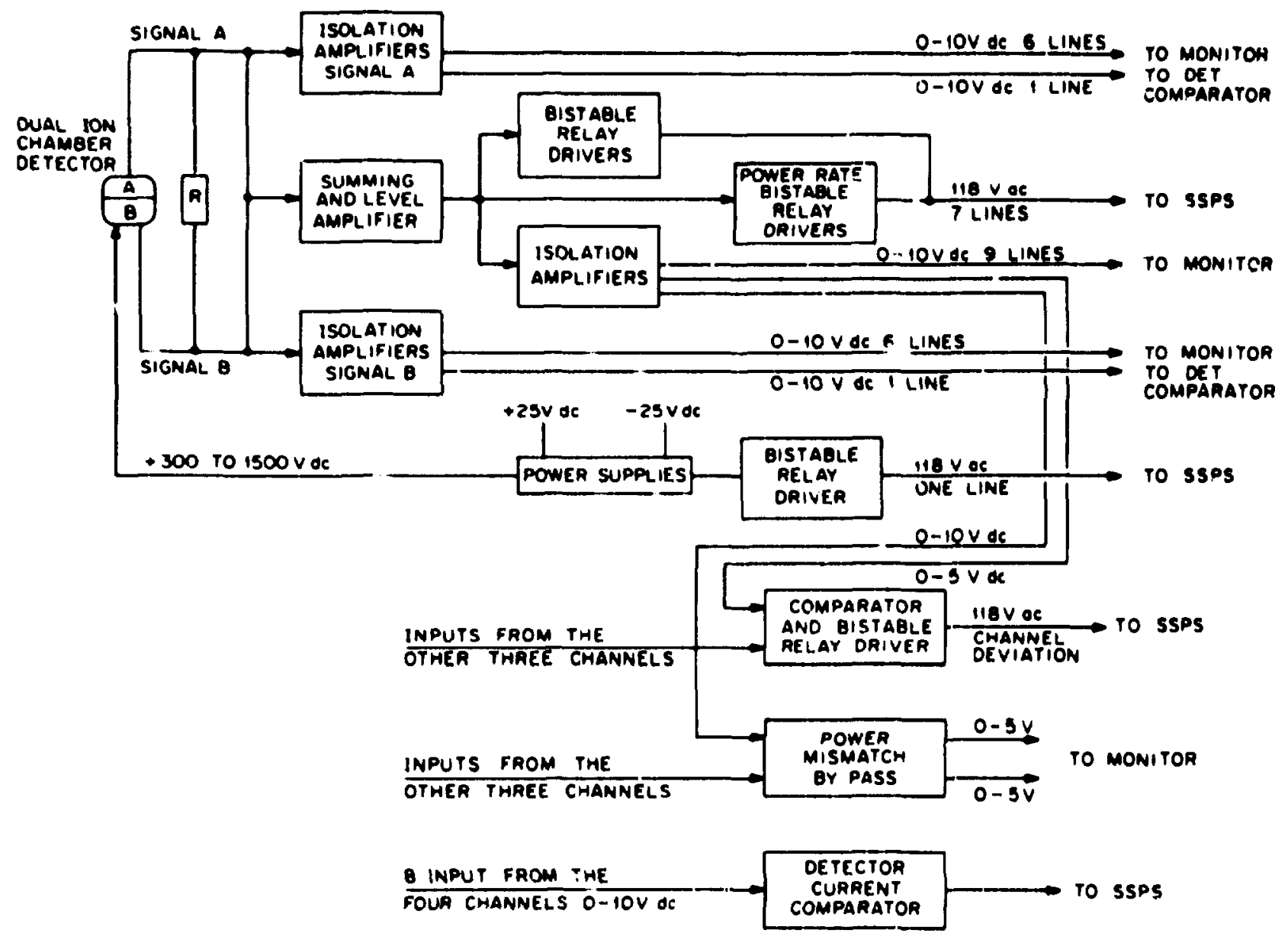

Fig. 3.5. Simplified Block Diagram of One Channel of the FourChannel NIS. 
withdram, the consequences to reactor safety are 1 inited to very minor fuel damage, if any. Minor fuel danage would not release any radioactivity outside the RCS. During normal operations, cost of the rods are fully witndram from the core, and rod witindrawal accidents result in only a minor excursion. 10 The RCS "failure-monitoring circuit" if operating correctly would block surther rod withdrawals. If the reactor parameters did become abiorma?, a reactor scram would result. Danages to the RCS would not prevent a scran since the shutdown rods are completely separate from the control rods and are not affected by the rod control system.

The various instrument and control equipment paver supplies wtich are connected to the unshielded electrical power circuits will be subjected to EMP voltage transients with peaks that range from about 200 to $\mathbf{8 8 0 0}$ volts. If these power supplies are not adequately protected, solic stali components may be damaged. Such damages would likely result in a loss of voltage from the damaged power supply. Danaged components could, however, cause a regulated power unit to supply unregulated voltages, voltages that are either too large or too small for oroper use by the equipment connected to the power supply.

The results of our analysis of the PAR instrumentation and controls are presented in Table 3.2. The important points of entry (POE's) foEMP energy are listed for each system. The peak EMP surge and the transient protection at each POE are also listed in the table along with the important circuit parameters and the probable EMP effects.

\subsubsection{BWR Instrumentistion and Controls}

The important instrumentation, control, and protection systems associated with the General Electric BUR nuclear steam supply system consist of the neutron monitoring system, rod block monitor system (RBM), process variable instrumentation, and the RPS. The neutron monitoring system for use when the reactor is operating at power levels consists of the local power range monitor system (LPRM) and the average power range monitor system (APRM). 
Table 3.2. EMP Effects on PWR Instrumentation and Controls

\begin{tabular}{|c|c|c|c|c|c|c|}
\hline Sys tem & POE & $\begin{array}{l}\text { EMP Transient } \\
\text { Peak }\end{array}$ & $\begin{array}{c}\text { Noise and Surge } \\
\text { Protection }\end{array}$ & $\begin{array}{l}\text { Line Voltage } \\
\text { or Current }\end{array}$ & $\begin{array}{l}\text { Electronic } \\
\text { Components }\end{array}$ & $\begin{array}{c}\text { Probable EMP } \\
\text { Effects }\end{array}$ \\
\hline NIS & Detector Cable & $0.5: A$ & $\begin{array}{l}\text { Triaxial Cable in } \\
\text { Conduit }\end{array}$ & $0-4 \mathrm{inA}$ & $\begin{array}{l}\text { IC's, } \\
\text { Diodes, and } \\
\text { Transtents }\end{array}$ & None \\
\hline - _ - - - & $\begin{array}{c}\text { SSPS Cable } \\
\ldots \ldots \ldots\end{array}$ & $0.3 \mathrm{~V}$ & $\begin{array}{l}\text { Electrostatically } \\
\text { Shielded Trans- } \\
\text { former, Shielded } \\
\text { Twisted Pair }\end{array}$ & $118 \mathrm{Vac}$ & $\begin{array}{l}\text { Solid State } \\
\text { Switch }\end{array}$ & None \\
\hline NIS & Monitor Lines & $0.8 \mathrm{~V}$ & Isolation Amplifters & $0.10 \mathrm{Vdc}$ & Transistors & None \\
\hline NIS & Electrical Power & $8.8 \mathrm{kV}$ & $\begin{array}{l}\text { Electrostatically } \\
\text { Shielded Trans- } \\
\text { former }\end{array}$ & $\begin{array}{l}118 \mathrm{Vac} \\
\text { Ins trument } \\
\text { Power }\end{array}$ & $\begin{array}{l}\text { Diodes, } \\
\text { Trans is tors }\end{array}$ & None \\
\hline PV & Detector Cable & $22 \mathrm{~mA}$ & $\begin{array}{l}\text { Shielded Twisted } \\
\text { Pair Cable }\end{array}$ & $10-50 \mathrm{~mA}$ & Transistors & None \\
\hline PV & SSPS Cable & $0.8 \mathrm{~V}$ & $\begin{array}{l}\text { Shielded Twisted } \\
\text { Pair Cable }\end{array}$ & $\begin{array}{l}120 \text { Vac or } \\
24 \mathrm{Vdc}\end{array}$ & $\begin{array}{l}\text { Dindes, } \\
\text { Transistors }\end{array}$ & None \\
\hline PV & Monitor Lines & $0.8 v$ & $\begin{array}{l}\text { Shielded Twisted } \\
\text { Pair Cable }\end{array}$ & $\begin{array}{l}118 \mathrm{Vac} \text { or } \\
0-10 \mathrm{Vdc}\end{array}$ & $\begin{array}{l}\text { Diodes, } \\
\text { Transistors }\end{array}$ & None \\
\hline PV & $\begin{array}{l}\text { Unit Electrical } \\
\text { Power }\end{array}$ & $8.8 \mathrm{kV}$ & $\begin{array}{l}\text { Electrostatically } \\
\text { Shielded Trans- } \\
\text { former }\end{array}$ & $120 \mathrm{Vac}$ & $\begin{array}{l}\text { Solid State } \\
\text { Circultry }\end{array}$ & None \\
\hline PV & $\begin{array}{l}\text { Transmitter Power } \\
\text { Supply }\end{array}$ & $8.8 \mathrm{kV}$ & $\begin{array}{l}\text { Caracitor Diffei- } \\
\text { en:ial Transient } \\
\text { Proiection }\end{array}$ & $118 \mathrm{Vac}$ & Diodes & $\begin{array}{l}\text { Possible } \\
\text { Loss of } \\
\text { Power }\end{array}$ \\
\hline
\end{tabular}


Table 3.2. EMP Fffects on PWR Instrumentation and Controls (cont'd)

\begin{tabular}{|c|c|c|c|c|c|c|}
\hline System & POE & $\begin{array}{l}\text { EMP Trainsient } \\
\text { Pr!ak }\end{array}$ & $\begin{array}{l}\text { Noise and Surge } \\
\text { Protection }\end{array}$ & $\begin{array}{l}\text { Line Voltage } \\
\text { or Current }\end{array}$ & $\begin{array}{l}\text { Electrontc } \\
\text { Components }\end{array}$ & $\begin{array}{c}\text { Probable EMP } \\
\text { Effects }\end{array}$ \\
\hline SSPS & Input Cables & $0.8 \mathrm{~V}$ & $\begin{array}{l}\text { Shielded Twisted } \\
\text { Pair Cables, Relay } \\
\text { lsolation, Diode } \\
\text { Surge Protection }\end{array}$ & $118 \mathrm{Vac}$ & IC's & None \\
\hline SSPS & $\begin{array}{l}\text { Reactor Trip } \\
\text { Cable }\end{array}$ & $0.8 \mathrm{~V}$ & Shielded Cable & $48 V$ & $\begin{array}{l}\text { Trans is tors, } \\
\text { Diodes }\end{array}$ & None \\
\hline SSPS & ESF Lir.3s & $0.8 \mathrm{~V}$ & $\begin{array}{l}\text { Relay Isolation, } \\
\text { Shielded Twtsted } \\
\text { Pairs }\end{array}$ & $\begin{array}{l}48 \mathrm{~V} \text { or } \\
118 \mathrm{Vac}\end{array}$ & $\begin{array}{l}\text { Transistors, } \\
\text { Dlodes }\end{array}$ & None \\
\hline SSPS & $\begin{array}{l}\text { Multiplexed } \\
\text { Monitor Lines }\end{array}$ & $0.8 \mathrm{~V}$ & $\begin{array}{l}\text { Shielded Twisted } \\
\text { Pair Cables, Signals } \\
\text { Reset Periodically, } \\
\text { isolation Amplifiers }\end{array}$ & $\begin{array}{l}\text { Several } \\
\text { Volts }\end{array}$ & $\begin{array}{l}\text { Solid State } \\
\text { Circultry }\end{array}$ & None \\
\hline SSPS & Electrical Power & $8.8 \mathrm{kV}$ & No Protection & $120 \mathrm{Vac}$ & $\begin{array}{l}\text { Diodes, } \\
\text { Transistors }\end{array}$ & None \\
\hline RCS & Contro? Lines & $0.8 \mathrm{~V}$ & $\begin{array}{l}\text { Relay Isolation, } \\
\text { Snialded Cables }\end{array}$ & $118 \mathrm{Vac}$ & IC Logic & None \\
\hline RCS & Monitoring Lines & $0.1 V$ & $\begin{array}{l}\text { Relay Isolation, } \\
\text { Snielded Cables }\end{array}$ & $\begin{array}{l}0-10 \mathrm{~V} \text { or } \\
118 \mathrm{~V}\end{array}$ & $\begin{array}{l}\text { Solid State } \\
\text { Circultry }\end{array}$ & None \\
\hline RCS & Magnetic Jack Cables & $40 V$ & Metal Cable Runs & $\begin{array}{l}260 \mathrm{~V} \\
\text { puised dc }\end{array}$ & SCR's & None \\
\hline RCS & Electrical Power & $40 \mathrm{~V}$ & $\begin{array}{l}\text { MG Set Isolation, } \\
\text { Metal Cable Runs }\end{array}$ & $260 \mathrm{~V}$ & SCR's & None \\
\hline
\end{tabular}


The LPRM system takes inpuis from sensor cables cornected to miniature ionization chambers Jistributed throughout the reactor core. The sensor cables are normally RG-59B/U coaxial cables. The LPRM system consists of amplifiers and readout equitwent which are normally located in the control room. The APRM system averages the output signals from selected LPRM amplifiers. A blozk diagram of the neutron monitoring system is shown in Fig. 3.6. Also included in the figure is the RBM system.

The RBM consists of two channels, 1 and 2, wich monitor the local neutron flux levels during the withdrawal of a selected control rod. If the monitored f Iux level exceeds preset limits, the RBM generates irip sigrials to actuate rod inhibit and annunciator circuits. The RBM receives inputs from the LPRM's, APRM's, and flow units. The flow units measure reactor recirculation flow.

The LPRM, APRM, and RBY are normally arranged in adjacent cabinets. The primary points of entry of EMP energy for these systems are the cables entering the three cabinets as shown in Fig. 3.6(b). The Nis cables that transmit low level signa!s are either shielded coaxiai or twisted pair cables. The EMP transients that would be induced in these cables have peak amplitudes which are on the same order of magnitude as the normal operating signals. These transients are not expected to have any effect on the HIS. The 120-V contro! and power circiits of ten enfloy unshielded cables. These circuits, however, have relay isolation and/or diode surge suppressors. Thus, again EMP surges are not expected to do any damage with the possibie exception of the various system power supplies which have not been provided with transient protection.

The BWR reactor prctection system used in current plants (BWR-4 and older plants) employs many re?ays in a four-channel, two-out-offour logic protection system. A simplified diagram of the RPS is shown in Fig. 3.7. The RPS operates on a fail-safe basis; i.e., if oower fails, : scram signal is generated and, if a relay fails, the most likeiy failure mode will cause a scram.

The motor-generator sets that provide power to the RPS will also provide isolation from EM.P transients on the emergency power buses $A$ 


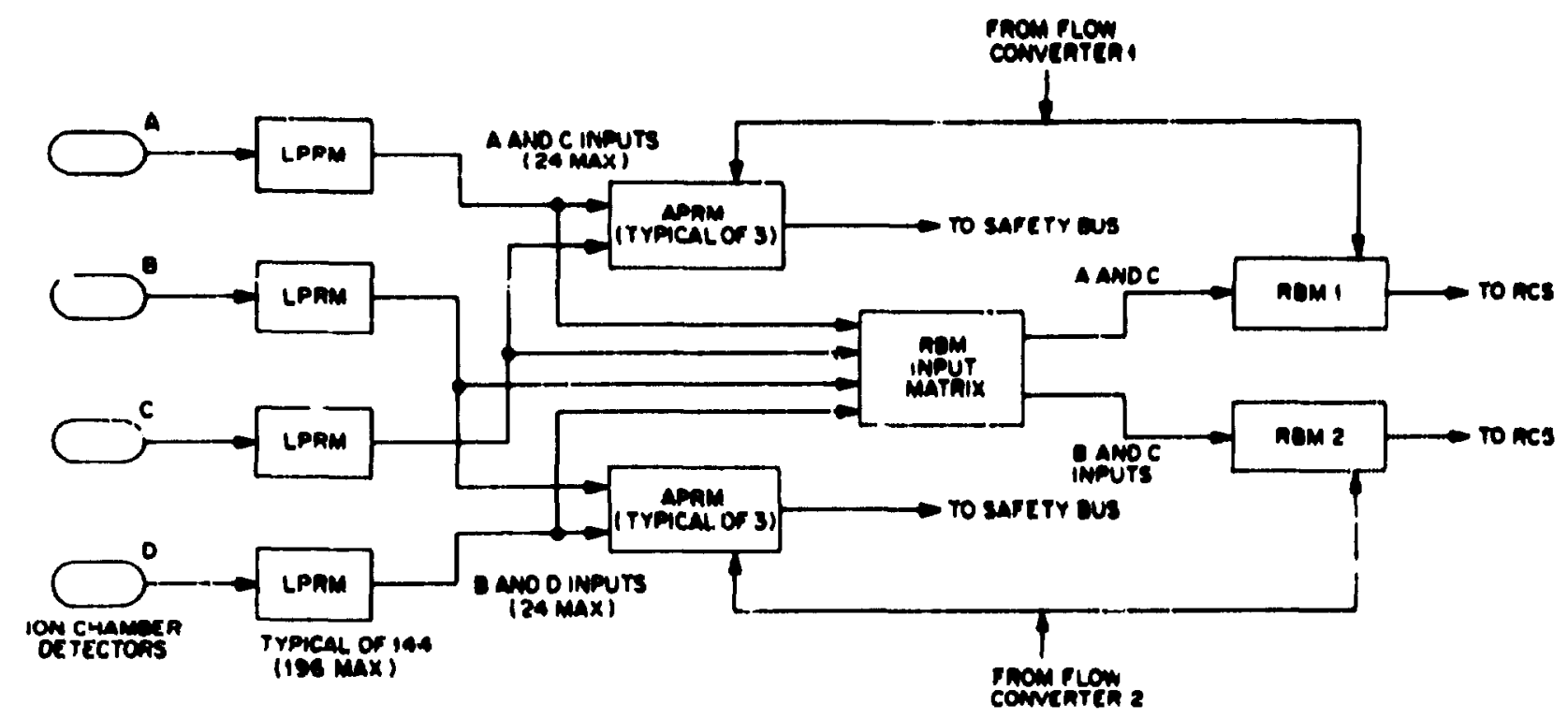

(0) Dewen nange moniron QLock OManala

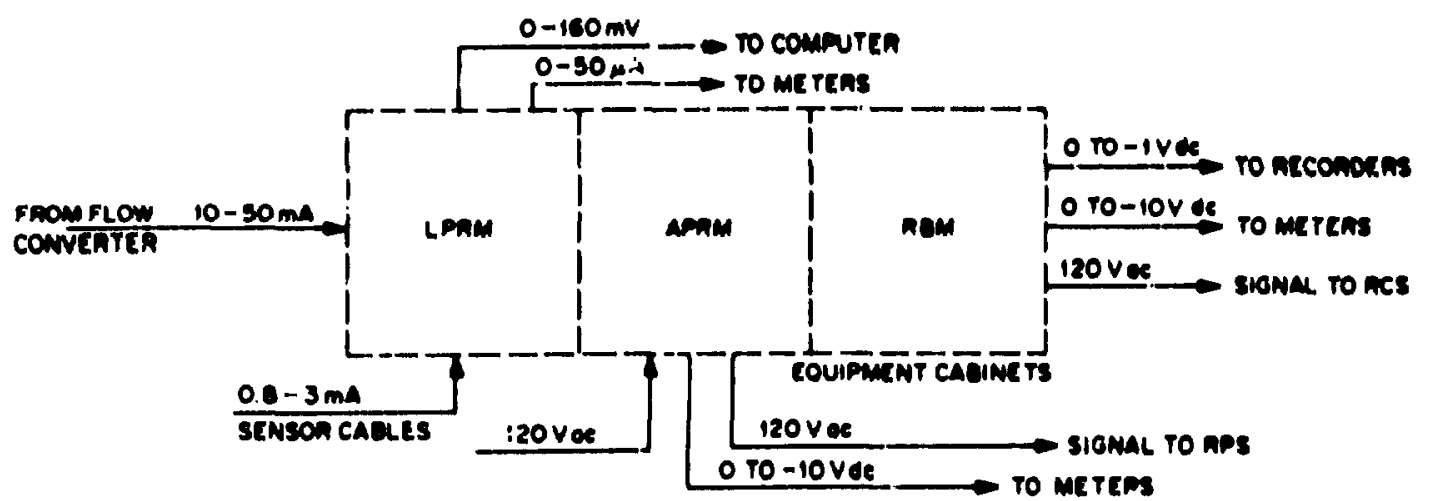

(b) nowea hange mowiton sYstem and EMP pOr's

Fig. 3.6. BWR Power Range Nuclear Instrumentation System. 
OANL - ONG 77-3794

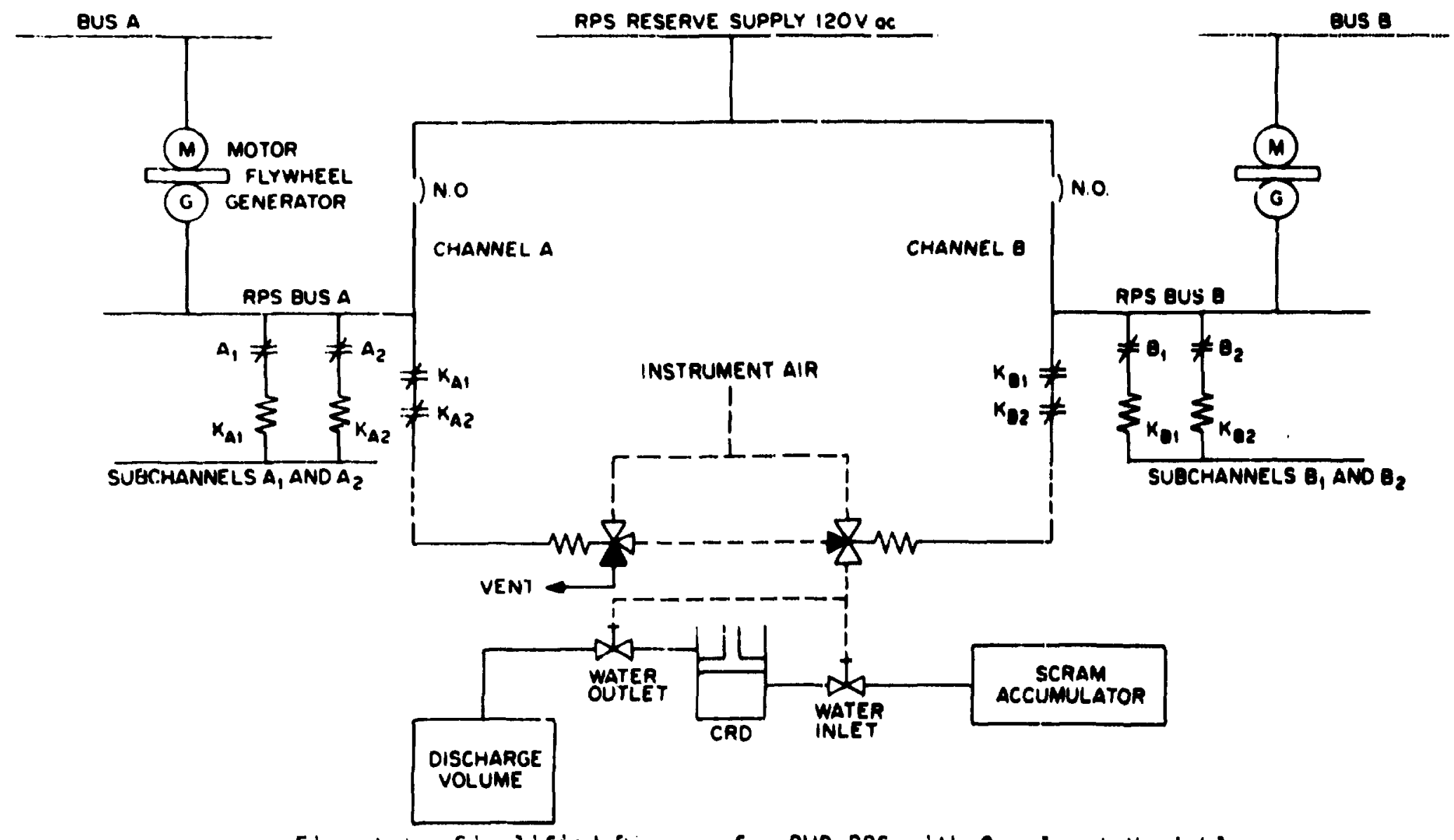

Fiy. 3.1. Simplified Uiagram for BWR RPS with One Input Varlable (No. 1) Shown. 
and 8 . EMP surges will be induced in the ain channe? circuits $A$ and B. EP surges will also be induced in the subchannel circuits. Mechanical relays are rather "hard" components wich are not easily daaged by transients. Since the transient: are not likely to have aplitudes ten times greater than the noral operating signal, no damage is expected. Level and pressure switches my experience sparkovers wich would indicate that setpoints have been exceeded. Such spartovers may cause an unnecessary scram.

The results if our analysis of the safety related BR instrumentation and control systens are presented in Table 3.3. This table is sinilar to Table 3.2 for the PuR. The PY instrumentation is corsidered as input for the RPS in Table 3.3.

\subsection{The Reactor Monitoring Systen}

The reactor monitoring system is related to plant safety only through the actions of the operator. False inforsation may be generated by EMP as a result of damages to some of the instrumentation power supplies. For the PUR SSPS, damages to the power supply may al so result in false information being sent to the monitor computer. ERP transients induced on the 5-10 V multiple twisted pair shielded signal cables from the PUR SSPS, NIS, and the PV eqLipment wiil have peaks of less than 1 volt. These transients should have little or no eifect on the monitoring systen. Any logical upsets that might occur from Enf signal line transients would be quickly reset by the PUR manitoring system and woild not be seen by the operator.

In the BUR monitoring system, the computer monitors inputs from the various nuclear auxiliary systens. Neutrol, flux, controi rod position, process variables, and input variables to the RPS are monitored by the computer. These data are read periodically. EMP transients in the computer 160-mv input cables would likely cause logical upsets. However, these upsets would be reset after the transient was dissipated. It is possible, however, that false signals could be received by the computer as a result of danages to unprotected power supplies in the instrumentation and control systems. 
Table 3.3. BWR Instrumentation and Control Systems

\begin{tabular}{|c|c|c|c|c|c|c|}
\hline System & POE & EMP Surge Peak & $\begin{array}{l}\text { Noise and Surge } \\
\text { Protection }\end{array}$ & $\begin{array}{l}\text { Line Vol tage } \\
\text { or Current }\end{array}$ & $\begin{array}{l}\text { Electronic } \\
\text { Components }\end{array}$ & $\begin{array}{c}\text { Probablu Earf } \\
\text { Effects }\end{array}$ \\
\hline NIS & $\begin{array}{l}\text { RG-59B/U Sensor } \\
\text { Cable in Conduit }\end{array}$ & 8 . A & Shie?ding & $0.8-3.0 \mathrm{~mA}$ & IC's & None \\
\hline NIS - - & $\begin{array}{l}\text { Flow Converter } \\
\text { Sensor Cable }\end{array}$ & $22 \mathrm{~mA}$ & $\begin{array}{l}\text { Shielded Twisted } \\
\text { Pair, Oiode Surge } \\
\text { Suppression }\end{array}$ & $10-50 \mathrm{~mA}$ & IC's & None \\
\hline NIS & $\begin{array}{l}\text { Computer input } \\
\text { Circuits }\end{array}$ & $800 \mathrm{mV}$ & $\begin{array}{l}\text { Shielded Twisted } \\
\text { Pairs }\end{array}$ & $15.0 \mathrm{mt}$ & IC's & None \\
\hline NIS & $\begin{array}{l}\text { Meter and Recorder } \\
\text { Inputs }\end{array}$ & $220 \mathrm{~V}$ & $\begin{array}{l}\text { Relay lsolation, } \\
\text { Diode Spike } \\
\text { Suppressors }\end{array}$ & $\begin{array}{l}0-50: A \text { or } \\
0 \text { to }-10 \mathrm{~V}\end{array}$ & Transistors & None \\
\hline $\begin{array}{l}\text { NIS } \\
\text { (RBM) }\end{array}$ & $\begin{array}{l}\text { RCS Inputs vid } \\
\text { Unsnielded Multi- } \\
\text { wire rable }\end{array}$ & $80 \mathrm{~V}$ & $\begin{array}{l}\text { Short Cable Run } \\
\text { to Adjacent } \\
\text { Cabinet }\end{array}$ & $120 \mathrm{Vac}$ & Relays & Non: \\
\hline NIS & $\begin{array}{l}\text { RPS Inputs vid } \\
\text { Unshielded Multi- } \\
\text { wire Cable }\end{array}$ & $80 \mathrm{~V}$ & $\begin{array}{l}\text { Short Cable Run } \\
\text { to Adjacent } \\
\text { Cabinct. }\end{array}$ & $120 \mathrm{Vac}$ & Rolays & Mone \\
\hline NIS & $\begin{array}{l}\text { Instrument Power } \\
\text { Cable }\end{array}$ & $8.8 \mathrm{kV}$ & $\begin{array}{l}\text { MG-sets, Powerline } \\
\text { Filters }\end{array}$ & $120 \mathrm{Vac}$ & $\begin{array}{l}\text { Power Supply } \\
\text { Transformers } \\
\text { and Solld } \\
\text { State Compo- } \\
\text { nents }\end{array}$ & $\begin{array}{l}\text { Possibla } \\
\text { Damage to } \\
\text { Supplites. } \\
\text { Loss of } \\
\text { Power }\end{array}$ \\
\hline RPS & $\begin{array}{l}\text { Proress fariable } \\
\text { Inputs }\end{array}$ & $22 \mathrm{~mA}$ & $\begin{array}{l}\text { Shielded Twisted } \\
\text { Pairs }\end{array}$ & $10-50 \mathrm{inA}$ & $\begin{array}{l}\text { Muchanical } \\
\text { and Solta } \\
\text { State Relays }\end{array}$ & Mone \\
\hline
\end{tabular}


Table 2.3. 3WR Instrumentation and Control Systems (cont'd)

\begin{tabular}{|c|c|c|c|c|c|c|}
\hline System & POE & EMP Surge Peak & $\begin{array}{c}\text { Noise and Surge } \\
\text { Protection }\end{array}$ & $\begin{array}{l}\text { Line Voltage } \\
\text { or Current }\end{array}$ & $\begin{array}{l}\text { Electronic } \\
\text { Components }\end{array}$ & $\begin{array}{c}\text { Probable EMP } \\
\text { Effects }\end{array}$ \\
\hline RPS & $\begin{array}{l}\text { Main Steam Line } \\
\text { Radia+ } \text {, Monitor } \\
\text { Input }\end{array}$ & $220 \mathrm{~mA}$ & $\begin{array}{l}\text { RG-59B/U Shielded } \\
\text { Couxial Cable }\end{array}$ & $10-50 \mathrm{~mA}$ & $\begin{array}{l}\text { Solid State } \\
\text { Relay }\end{array}$ & None \\
\hline RPS & $\begin{array}{l}\text { Eight Conductor } \\
\text { Unshielded Cabiss } \\
\text { used with Valve } \\
\text { Controls and } \\
\text { Pressure and } \\
\text { Level Switches }\end{array}$ & $1 \mathrm{kV}$ & None & $120 \mathrm{Vac}$ & Relays & $\begin{array}{l}\text { Pressure } \\
\text { and Level } \\
\text { Switches } \\
\text { May Spark } \\
\text { Over for } \\
\text { One Half } \\
\text { of a } 60 \mathrm{~Hz} \\
\text { Cycle }\end{array}$ \\
\hline RPS & RPS Power Bus & $8.8 \mathrm{kV}$ & $\begin{array}{l}\text { MG-Set:S, Spike } \\
\text { Suppressor Filters }\end{array}$ & $120 \mathrm{Vac}$ & Relays & None \\
\hline RPS & $\begin{array}{l}\text { Cable to Scram } \\
\text { Solenoid }\end{array}$ & $0.76 \mathrm{~V}$ & $\begin{array}{l}\text { Unshielded Cable } \\
\text { in Conduit }\end{array}$ & $120 \mathrm{Vac}$ & Relays & None \\
\hline RPS & $\begin{array}{l}\text { Annunciator and } \\
\text { Computer Inputs } \\
\text { to the Remote } \\
\text { Electronic Cabi- } \\
\text { net }\end{array}$ & $80 \mathrm{~V}$ & $\begin{array}{l}\text { Unshielded Cables } \\
\text { fun in Conduit } \\
\text { to Nearby Cabinet }\end{array}$ & $120 \mathrm{Vac}$ & Reliyys & None \\
\hline
\end{tabular}


False information as a result of EMP effects on the reactor monitoring system wili be analyzed by the cortrol room personnel. In most cases, the conclusion of the operator will be that ons or more parameters are out of bounds. The operator may decide that a reacter shutdown is necessar $r_{j}$ and scram the reactor.

\subsection{Plant Electrical Power}

The plant electrical power systems are the off site auxiliary power. the nuclear unit auxiliary power, emergency auxiliary power supplied by diesel-driven generators, and the inverter-charger battery power supply. The auxiliary power voltage is usually 4000 volts or 6900 volts. This voltage is used to power the large motors throughout the piant. Lower voltages such as 400 volts, 240 volts, ard 120 volts are obtained from stepdown transformers to power smal! mociors and other plant auxiliary loads.

The loss of the off-site auxiliary power will scram (shut cown) the reactor. The auxiliary systenis essential to a safe shutdown arp transferred to the diesel generators. Essential instrument and control power is maintained by the battery-ir rter power supply.

EMP may interrupt auxi? iary power to the safety loads by interacting with the differential relays. Relatively low-level VHF fields have been found to cause false operation of a differential relay, apprirently by interacting with the relay's conirol circuits. 11 Also, EMP transients in lower voltage branch circuits may cause flashovers and initiate braaker action to disconnect lhose circuits and interr.pt auxiliary power to low-voltage lrads.

EMP trarisients in the diesel control circuits may also interrupt auxiliary diesel-generator power. However, many plants have installed their diesel-generator control cables in conduit. The control circuits may also employ shielded cables. Such shielded diesel-generator control circuits are unlikely to be affected by EMF.

EMP transients in the auxiliary, control, and instrument power cables connected to the baitery inverter-charger system could result in damage to the system components Lightning damage does occur to invertercharger systems at remote microwave relay sites even thougn they are. 
protected by lightning arresters. Damage to the battery-charger control circuit may cause the charger to further damage itself and the batteries. However, damage to nuclear plant chargei-inverter systems by aMP is considered unlikely since the inost probable EMP current surges in the auxil iary, control, and instrument power cables are about two orders of magnitude smaller than an average lightning surge.

\section{CONSEQUENCES, COUNTERMEASURES, ANO CONCLUSICNS}

\subsection{EMP Events}

In this section, we examine the consequences of EMP on nuclear power plants by postulating possible events due to EMP. One or more events lead to a consequence. Due to the limited scope of this study, the probabilities of events have not been computed. However, we consider consequences other than the false actuation of scram or of the engineered safety feature circuits only as very remote possibilities.

In considering the col.sequences of EMP, we assume that the plant is operating at full power, the operator is unaware of EMP effects, and no special EMP procautions have been implemented. The consequences discussed here are the most obyious and are not necessarily a complete set. They are presented in an approximate order of increasing significance. Since the more serious consequences require more events, we may surmise that they are less likely to occur than the less serious consequences.

\subsection{A Reactor Scram}

The most likely result of one or more EMP events is an unscheduled shutdo:n of the $\mathrm{pl}$ ?.nt. A reactor scram signal may be generated by a loss of power from the various instrument or control power slipplies due to EMP surge effects. A iuss of off-site power due to a power blackout on the entire grid as a result of muitiple EMP's will also cause a scram. A loss of power to the large motors due to circuit breakers or differential relays responding to EMP transients may also scram the 
reactor. The relativaly large number of independent everits caused by EMP that can possibly cause a scram makes it a likely possibility.

\subsection{Actuation of Safety Systems}

The false activation of safety systems is another possible consequence of EMP. For ex.mple, the loss of power to the pump motors in the PWR chemical and volume control system could result in a pressure drop in the primary loop. Cver an extended time period, the pressure could drop low enough to actuate the safety injection system. Powe: could be lost for an extended period due to multiple EMP's. If a single EMF tripped the pump treal:ers, they would probably be quickly reset by the plant personnel. If, on the other hand, multiple EMP's continued to trip the breakers each time they were reset, the operator would probably conclude that major problems existed in the plant electrical system and discontinue the attempt to restore power.

\subsection{Loss of Electrical Auxiliary Power}

The less of all auxiliary plant power is a possible consequence of multiple EMP's. Several EMF events are necessary to make this consequence possible. They are as follows. First, EMP scrams the reactor. 'iinutes later, an EMP-caused power grid blackout occurs, and off-site power is lnst. The plant power circuits are then automatically transferred to the standby diesel generators. EMP-induced flashovers in the auxiliary power circuits result in iarge fault currents. Power trains $A$ and $B$ are then shut down by fault-current trips, and all auxiliary power is lost.

For the PWR, the steam-driven auxiliary feedwater pump could be employed, along with the natural circulation in the RCS, while the auxiliary power circuits are being examined. Without auxiliary power, the CVCS cannot maintain RCS pressure. If the auxiliary power is not restored before the RCS pressure falls below 650 psi, the accumulators would discharge 2000-ppm borated water into the RCS. Reactor startup would be delayed until the boron concentration was reduced. For the 
BHR, the steam-driven main feedwater pumps, reactor core isolation cooling (RCIC) pumps, or other steam-driven pumps could be used to cool the reactor while the auxiliary circuits are being examined.

\subsection{Loss $c^{5}$ instrument ana Control Power}

EMP surges in the auxiliary power circuits, the $120 \mathrm{Vac}$ instrument circuits, and/or the control circuits could possibly damage the vital battery chargers and inverters. A complete loss of instrument and control power would scram the reactor and actuate most of the ESF systems. If the auxiliary power is available, ESF systems such as the PWR Safety Injection System (SIS), containment isolation system, and the auxiliary feedwater system would be activated.

EMP by itself is not, however, a serious threat to reactor safety, even in the unlikely event that all power, including control and instrument power systems, is lost due to multiple EMP's. Mndern power reactors have steam-driven pumps that could be used to remove the residual heat from the reactur. The steam-driven cooling system would be used only temporarily until electrical power is restored.

The PWR auxiliary feedwater system can cool the reactor by supplying water to the steam generators. The residual heat in the primary loop would be removed to the steam generators by natural convection. Auxiliary feedwater control is normally accomplisher by an air-operated control valve. If the air valves fail, manual operation can be used for contro1. 4 But without instrumentation the operator of the steamdriven auxiliary feedwater pump would not know the water level in the steam generators. It is possible, however, to know nitien the generators are full by observing the steam generator safety relief valves. Thus, plant personnel could observe the safety relief valves and stop the feedwater pump.

The BWR reactor core isolation cooling (RCIC) system has a steamdriven turbine pump that is driven by a portion of the decay heat steam from the reactor. ${ }^{6}$ This system operates independently of auxiliary power, plant service air, or external cooling water systems. The turbine pumps 
Can be manually controlled in conjunction with manually-operated valves to al low the RCIC system to cool the reactor.

\subsection{Countermeasures}

In considering EMP protection for nuclear power plants, it is important to ensure the safety of the public and the plant. It is rot necessary to ensure the continued operation of the plant in an intense multiple EMP environient. To provide this kind of protection would be very difficult and costly. Aithough EMP alone is not a serious threat to nuclear safety, it is conceivable that EMP-caused component failures in safety-related systems could go undetected and cause those syscellis to function improperly in the event of a nuclear plant malfunction. The countermeasures proposed below will greatly reduce the probability of serious damage to nuclear plants without significantly increasing the cost of the plant. The recommended colntermeasures are as follows:

1. All plants should be equipped with a nonelectrical cooling s/stem that can temporarily remove residual heat from the reactor in the event that all auxiliary electrical power is lost. Operating procedures should be developed for the emergency operation of this system in the event that all electrical power including control and instrument poser is lost.

2. In the event of an escalating international crisis, nuclear power plant operator: should he informed about the effects of EMP. They should also be instructed to trioroughly test all of the reactor inctrument, control, and safety systems, if a nuclear weapon is detonated at a high altitude within or near the continental U.S.

3. EMP transient protection should be provided for the emergency battery systems. Also, electrostatically shielded transformers should be emifloyed whenever possible for transient protection of important power supplies. And fast responding lightning arresters should be provided for the off-site, power bus at or near its entrance into the building. 


\subsection{Conclusions}

The most probable effect of EMP on a modern nuclear power plant is an unscheduled shutdown. EMP may also cause an extended shutdom by the urnecessary activation of some safety-related systens. In general, EMP would be a nuisance to nuclear plants, but it is not considered a serious thre;t to plant safety.

Countermeasures to minimize the effects of EAP have been recomended. Implementation of these recomendations would also increase the protection of the plant against damage by lightning, switching, and electromagnetic interference transients as well as general failures in electrical, control, and instrument power. 


\section{REFERENCES}

1. D. B. Ilelson, "EMP Impact on U.S. Defenses," Survive, 2(6), November-December 1969.

2. J. K. Baird, J. H. Marable, and D. B. Nelson, "Studies of iuclear Electromagnetic Pulse (EMP) Effects on Power Systems," Ariric3 ! Progress Repo: $c$, Civil Defense Research Project, March 1971March 1972, ORNL-4784, Oak Ridje National Laboratory, Dak Ridge, Tennessee.

3. P. R. Barnes. The Effects of Electromagnetic Pulse (EMP) on State and Local Radio Comminications, ORNL-4873, October 1973, Oak Ridge National Laboratory, Oak Ridge, Tennessee.

4. Systems Summary of a Westinghouse Pressurized Waier Peactor Nurlear Power Plant, Westinghouse Electric Corporation, Third Pririting, August 1973.

5. Sequoyah Nuclear Power Plant, Units 1 and 2, License Application, Final Safety Analysis Report.

6. General Description of a Boiling Water Reactor, General Electric Company, 12th orinting, May 1974.

7. P. R. Barnes and J. H. Marable, Transient Response of Illci izar Power Plant Catles to High-Altitude Huclear Electromagnetic Pulse (E:MP). ORNL-5152, May 1976, Cak Pidge Pational Laboratory, Oak Didae, Tennessee.

8. J. H. Marable, P. R. Barnes, and D. B. Nelson, Power System EMP Protection, ORNL-4958, March 1975, Oak Ridge :ational Laboratory, Oak Ridge, Tennessee.

9. P. W. Manweiler, Effects of Nuclear Eiectromagnetic Pulse (rMp) on Synchroncus stability of the Electric Power System. ORNiL-4919, IUvember 1975, Nak Ridge iational Laboratory, Oak Ridge. Tennessee.

10. Г. A. Pisher, Jr., An Evaluation of the Rod Ejection Accident in bie: inghnuse Pressurized Water Reactors Using Spatial Kinetics Methods, WCAP-7588, December 1971, Westinghouse Corporation, Pittsburgh, PA.

11. "False Operation of GF Type 12STO 1585A Differential Pelays," :iRC Dorket iros. 50-349/364, December 3, 1975. 
91. Research \& TEuinical Support Division, Oak Ridge Operutions Office, Oak Ridge, IN 37830

92. Sandia Laboratories, P. 0. Box 5800, ATT:N: C. Vittatoe, Albuquerque, HH 87115

93. 'ames L. Shea, U.S. Nuclear Regulatory Comission, 'Iashington, DC 20555

94. Hayne L. Smalley, Safety \& Environmentai Contro! Division, Federal 0ffice Building, Oak Ridge, TN 37830

95. Lewis V. Spericer, Center for Radiation Research, Radiation Theory Section, National Bureau of Standards, Hashington, DC 20234

96. Frank P. Szabo, Defense Research Establishment, Dttawa, Oritario, Canada KIA 024

97. U.S. Department of the Interior, Defense Electric Powier Administration, 18th \& C Streets, N.W., ATTN: Dr. Phillip Swart, Washington, DC 20240

98. Energy Research and Uevelopment Administration, Headquarters Report Library, G-107, Germart,own, MD 20545

99. James E. Watson, Manager of Power, Tennessee Valley Authority, Power Bui iding, Chattanooga, TN 37401

100. Louis F. Wouters, Lawrenre Livermore Laboratory, Techrical Information Division, P. 0. Box 808, Livermore, CA 94551

101-292. Given distribution as shown in TID-4500 under Applications of Explosions category (25 copies-NTIS; 